Tourism and the Public Sector in England since 2010: a Disorderly Transition?

This manuscript has been accepted for publication in the peer-reviewed academic journal, Current Issues in Tourism. The paper appeared online on 19 November 2012 at the following address: http://www.tandfonline.com/doi/full/10.1080/13683500.2012.733356. The anticipated date for print publication is in 2013.

Prof Tim Coles*, Dr Claire Dinan and Fiona Hutchison

t.e.coles@ex.ac.uk, c.dinan@ex.ac.uk, f.c.hutchison@ex.ac.uk

Centre for Sport, Leisure and Tourism Research, University of Exeter Business School.

Streatham Court, Rennes Drive, Exeter, Devon. EX4 4PU.

* Corresponding author 


\title{
Tourism and the Public Sector in England since 2010: a Disorderly Transition?
}

\begin{abstract}
The recent financial crisis has resulted in the restructuring and reorganisation of tourism production and consumption. Many states have cut public spending to reduce their deficits. However, there has been no analysis of the nature, extent or outcomes of such changes to state support for, or mediation of, the tourism sector. This paper examines how recent reforms enacted since the Coalition Government came to power in May 2010 have impacted on tourism governance and administration in England, and how they have been experienced as they have been unfolding. This paper argues, more generally, for a greater appreciation of sense-making in critical studies of tourism and public policy. More specifically, rapid reforms to the preferred nature and scale of state intervention have had destabilising effects. New localism, sub-regional bodies, and a desire in central government to reduce the contribution of the public purse to a minimum have introduced complexity and uncertainty to a previously ordered and understood system. The implications are that these reforms may frustrate other national policy aspirations they are intended to facilitate. As other states are also likely to downgrade their support for tourism, the paper demonstrates the importance of developing a deeper understandings of what happens as public sector support is withdrawn.
\end{abstract}

\section{Introduction}

The recent financial crisis has had several notable consequences for travel and tourism. High profile business casualties have been accompanied by turbulent visitor numbers and reoriented patterns of production (Jones 2009; Smeral 2009, 2010; Woodworth 2009; Pechlaner and Frehse 2010; Franke and John 2011; Reinhardt 2011; Smith 2011). As the crisis has deepened, the discourse has evolved, especially in Europe. Talk of the 'sovereign debt crisis' (Economist 2011), which is not just restricted to the Eurozone, emphasizes concerns about the inability of many countries to restructure, refinance or reduce the debts accrued from ambitious spending programmes in the past. In the United Kingdom (UK) the government had borrowed $f 163.4$ billion in the financial year 2009. Total debt had reached $f 893.4$ billion, equivalent to $62.1 \%$ of GDP (BBC 2010a). Upon its election, the new Conservative-Liberal Democratic Coalition Government committed itself to deficit reduction (HMG 2010a) so that by 2014-15 borrowing of $£ 37$ billion would be half of that planned by the previous Labour administration (Inman 2010). Public sector support for a wide range of activities, including tourism, was to be cut as a central part of this restructuring (Conservative Party 2010).

This paper examines how recent reforms enacted since May 2010 have impacted on tourism governance and administration in England. More particularly, it considers how they have been experienced by those expected to implement them, that is as change has been unfolding. Traditionally, the state in its various guises has played several important roles in organising tourism (Hall 2005a; Dredge and Jenkins 2007; Edgell et al 2008), and at a variety of spatial scales in addition to the national (Dredge and Jenkins 2003a, 2003b; 2012; Hall 2005b; Henriksen and Halkier 2009; Zahra 2010; Prokkola 2011). Not surprisingly then, the orthodox position within the academy has 
been to recognise and even advocate the continuing importance of engaged state participation in, and public sector support for, tourism development (Dredge and Jenkins 2003a; Hall 2008, 2010a; Zahra 2010). Over the past decade, one manifestation of this has been the considerable debate on a multiplicity of arrangements including partnerships, collaborations and networks by which to strengthen and grow the ties between the public sector and other (in many cases private sector) tourism actors (Tyler and Dinan 2001a, 2001b; Church et al 2001; Bramwell and Lane 2003, 2011; Treuren and Lane 2003; Anastasiadou 2008; O'Brien 2010; Dredge and Jenkins 2012). Conversely, very little is known about what happens when state intervention is radically reduced or withdrawn, nor the processes either spatially or organisationally of transition that accompany the stripping away of layers of public administration.

This paper argues, more generally, for a greater appreciation of sense-making in critical studies of tourism and public policy. Specifically, it contends that rapid reforms in the preferred nature and scale of state intervention have had destabilising effects that may conspire unexpectedly to prevent the achievement of the (other) national policy aspirations which they are intended to encourage over the current parliamentary term (i.e. to 2015). The paper unfolds in six further sections. In the next, we explore the recent relationship between political ideology and the governance of economic development as they relate to tourism policy and administration in England. The eradication of regional bodies by the Coalition Government has been such a fundamental shift from the previous administration that it is a challenge for scholars and practitioners to make sense of the disruption and its likely consequences. In the third section, we suggest that the existing conceptual toolbox on tourism policy is not fully-equipped for this purpose. Rather, there is considerable potential in adopting the Cynefin (Snowden 2002, 2005; Kurtz and Snowden 2003) framework from management science within studies of tourism policy. Section Four discusses the methods used to collect the empirical evidence on which this paper is based. This is prior to an examination in Section Five of the respective experiences within two types of sub-regional bodies that were expected to feature prominently in future tourism administration. In the sixth section, the changes are viewed through the Cynefin framework and the effects of this transition from an established and ordered system are discussed. The implications of this research for future studies of tourism policy are discussed in the final section.

\section{Background: From Regionalism to Localism in England}

The election of the coalition in May 2010 marked the end of thirteen years or three parliamentary terms of government by the left-of-centre Labour Party in the UK. Elected by a landslide in 1997, the New Labour project was characterized by its desire to preserve its long-held values (including solidarity, reducing inequality, fair access to services) through a new, innovative set of policies that reflected prevailing global conditions of the day. Central to this agenda was the continued belief in active government as a means by which to deliver policy aspirations (Giddens 2010). As Goodwin et al (2005) have demonstrated, one of the most prominent initiatives associated with New Labour was the devolution of government to the regions of the UK. For Webb and Collis (2000), this 'new regionalism' was legitimized by the apparent hollowing-out of the nation-state and the contention that regions were better placed to respond to the imperatives of globalisation.

A parliament in Scotland and assemblies in Wales and Northern Ireland were accompanied by greater regional administration in England. Government Offices were established throughout the country to take the organs of the state out of Westminster and make them more directly accessible, 
Figure 1: The location of LEPs with respect to former RDA boundaries

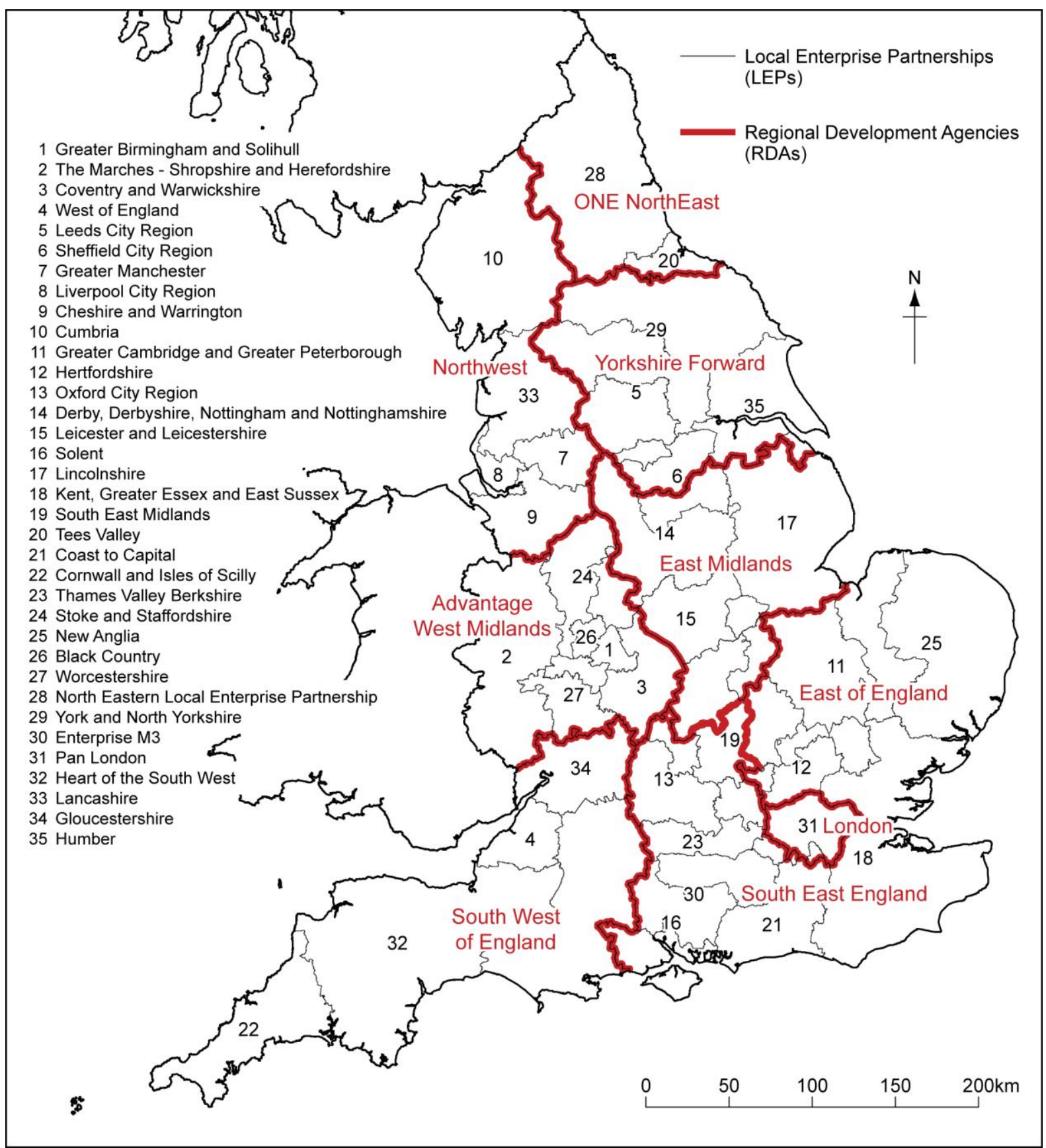

Source: adapted from BIS (2011b). C Crown Copyright 2011. URN 12/P113A @ Crown Copyright 2012. An Ordnance Survey/EDINA supplied service.

especially in new 'regional capitals'. Non-elected regional assembles (RAs) were established with both advocacy and scrutiny roles. RAs provided a channel of communication from local communities both to central government and their corresponding regional development agencies (RDAs). Moreover, they were intended to contribute to greater 'joined up government' by facilitating more effective, more responsive policy agendas as well as (sub-regional) partnerships to assist in their 
delivery (Fuller et al 2002). As the pinnacle of this programme, RDAs were launched in 1999 to promote economic and social development (see Figure 1; Lynch 1999; Lovering 1999; Jones 2001; Waters and Lawton-Smith 2002; Jones and MacLeod 2004). As publicly-funded bodies, RDAs were accountable to both central government and to their respective RAs (Harding et al 1999; Blackman and Ormston 2005) in terms of their statutory obligations to: further economic development and regeneration; promote business efficiency, investment and competitiveness; grow employment; enhance skills and employability; and contribute towards sustainable development (Mellows-Facer 2011a).

The result of this 'institutional' and 'scalar' turn (Jones 2001) was to fill in gaps within the spatial matrix of governance within England (Goodwin et al 2005). For some commentators, this arrangement had at least the potential to lead to greater policy co-ordination both within and between regions (Fuller et al 2002; Allmendinger and Tewder-Jones 2003; Henderson and Shutt 2004). Others noted the persistence -and in some cases accentuation- of particular regional inequalities because of the uneven nature of the rescaling process (Lloyd 1999; Gibbs and Jonas 2001; Goodwin et al 2002; Peck and McGuiness 2003). In the context of tourism, one of the unexpected outcomes of this 'new regionalism' was that the boundaries of RDA territories closely coincided with those of regional tourist boards (RTBs) in England. RTBs traced their origins back to the 1969 Development of Tourism Act and they were intended to deliver the broad aspirations of the then English Tourist Board (ETB, later VisitEngland), namely: to encourage improvements in the long-term economic performance and competitiveness of the tourist industry; increase public understanding of the value of tourism; maintain a balance between growth and capacity; extend the benefits of tourism spatially and temporally; and to increase the standard of provision of tourismrelated facilities (Shaw et al 1998: 216).

Beyond this spatial congruence, the activities of RTBs and RDAs were, in principle, mutuallyreinforcing in regions where tourism and leisure were essential components of the economy and society. RDAs were encouraged to foster relevant sub-regional partnerships to realise economic development goals (Fuller et al 2002). Meanwhile, to achieve their ambitions, RTBs had both to engage and leverage resources from further public, voluntary and particularly private sector partners (Shaw et al 1998). In the early stages, it was anticipated that RTBs would lead on regional tourism strategy and its implementation, but RDAs may lobby for a greater role if programmes were not successfully delivered (Church et al 2000: 320). For some early critics this was not so much 'joined-up government' as a duplication of effort. Nevertheless, in parallel and precipitated by the 2001 Foot-and-Mouth Crisis, RTBs started to struggle financially and remain sustainable as independent entities. Membership subventions and commission payments fell (see Coles 2003), as did settlements from government. As a result, throughout the last decade RDAs across England first funded the functions and later progressively assumed the roles of RTBs. Consequently, by the time of the 2010 election, there was no RTB independent of an RDA within England.

Despite this rationalisation process, there was a well-understood structure of public sector support for tourism prior to the 2010 election based on the region as the predominant spatial unit. RDAs had become responsible for tourism strategy development and implementation, including the promotion of regional destination brands. In the South West of England, for instance, the RDA through its 'RTB brand' South West Tourism, looked forward to refreshing its strategy (SWT 2010a). In many parts of the country, sub-regional destination management organisations (DMOs) had also been established ostensibly for more tactical operational reasons such as to promote local 
destination brands or fund visitor services such as tourist information centres; that is, operational functions beyond the remit of RDAs. Taking the form of public-private partnerships in many cases, in the South West as elsewhere in England, these largely followed county council or local authority boundaries because local government was the primary source of funding.

However, this established system was disrupted. In its pre-election mannifesto, the Conservative Party signalled its intent to disband the RDAs (Conservative Party 2010: 24) and this position was subsequently taken in the Coalition Agreement with the Liberal Democrats (Cabinet Office 2010: 10). RDAs represented 'big government' at its worse: they added another, unnecessary layer of bureaucracy; they required considerable public money to operate; and the returns on public investment were alleged to be poor (Taxpayers' Alliance n.d). Whether their records were as bad as portrayed is eminently contestable (Skeens 2007: England's RDAs 2010) and the real reason for their abolition has been interpreted as purely political (Kite 2010): precisely because they were so closely associated with the previous Labour administration, they had no future under the Conservatives. Instead, the Coalition advocated more locally-based (i.e. sub-regional) solutions to economic, social and environmental issues (Conservative Party 2010; Cabinet Office 2010; BBC 2010b); regions as constituted by RDAs were too large and inappropriate for directing investment or tailoring interventions.

RDAs were to be disbanded by April 2012. In their place, the government announced in June 2010 that it proposed to 'rebalance the economy towards the private sector' by creating Local Enterprise Partnerships (LEPs) to boost growth (Cable and Pickles 2010). This measure had a second purpose because it delivered major savings in public spending. Whereas the previous government had committed f1.7 billion, combined RDA budgets for 2011-12 were downgraded to $f 711$ million (Mellows-Facer 2011a; Appleyard 2010). In its White Paper on Local Growth, the government envisaged the roles of LEPs to include: setting key investment priorities; supporting (high growth) businesses; facilitation of planning; leading the reform of local business regulation; strategic housing delivery; boosting employability and employment; co-ordinating the leveraging of private funds; becoming involved in digital infrastructure; and exploring opportunities to develop renewable energy (HMG 2010b; Mellows-Facer 2011a: 5-6). Formed by businesses and local authorities, LEPs would essentially become a form of public-private partnership which would drive sustainable private sector-led growth and job creation in their area. Specifically in the context of this paper, LEPs would be responsible for setting local priorities for economic development and hence determining the relative importance of the tourism sector as well as the roles it should play in this respect.

Unlike RDAs, LEPs would have no core central government funding. Rather, they should be able to self-fund to cover their own daily administration costs and leverage private sector investment to achieve their objectives. However, they would be able to bid for the Regional Growth Fund (RGF, Mellows-Facer 2011b); that is, resources to help areas and communities at risk of being particularly affected by (other) public spending cuts (Mellows Facer 2011a: 7). At first, f1 billion was made available across 2011/2012 and 2012/2013 (BIS undated a), and the government further announced that LEPs would be able to bid for start-up funding from a $f 5$ million pot (Bounds 2011). In the summer of 2010, 62 proposals had been made to start LEPs, 35 had been agreed, and these had a quite different political geography to RDAs (Figure 2). Their size and scope varied significantly in terms of size of population and the number of local authorities which they covered. Some LEPs followed existing boundaries but they were intended to reflect functional economic areas and hence exist across prior local government boundaries (Mellows-Facer 2011a). As a result, several local 
Figure 2: The location of Local Enterprise Partnerships (LEPs) in England (June 2011)

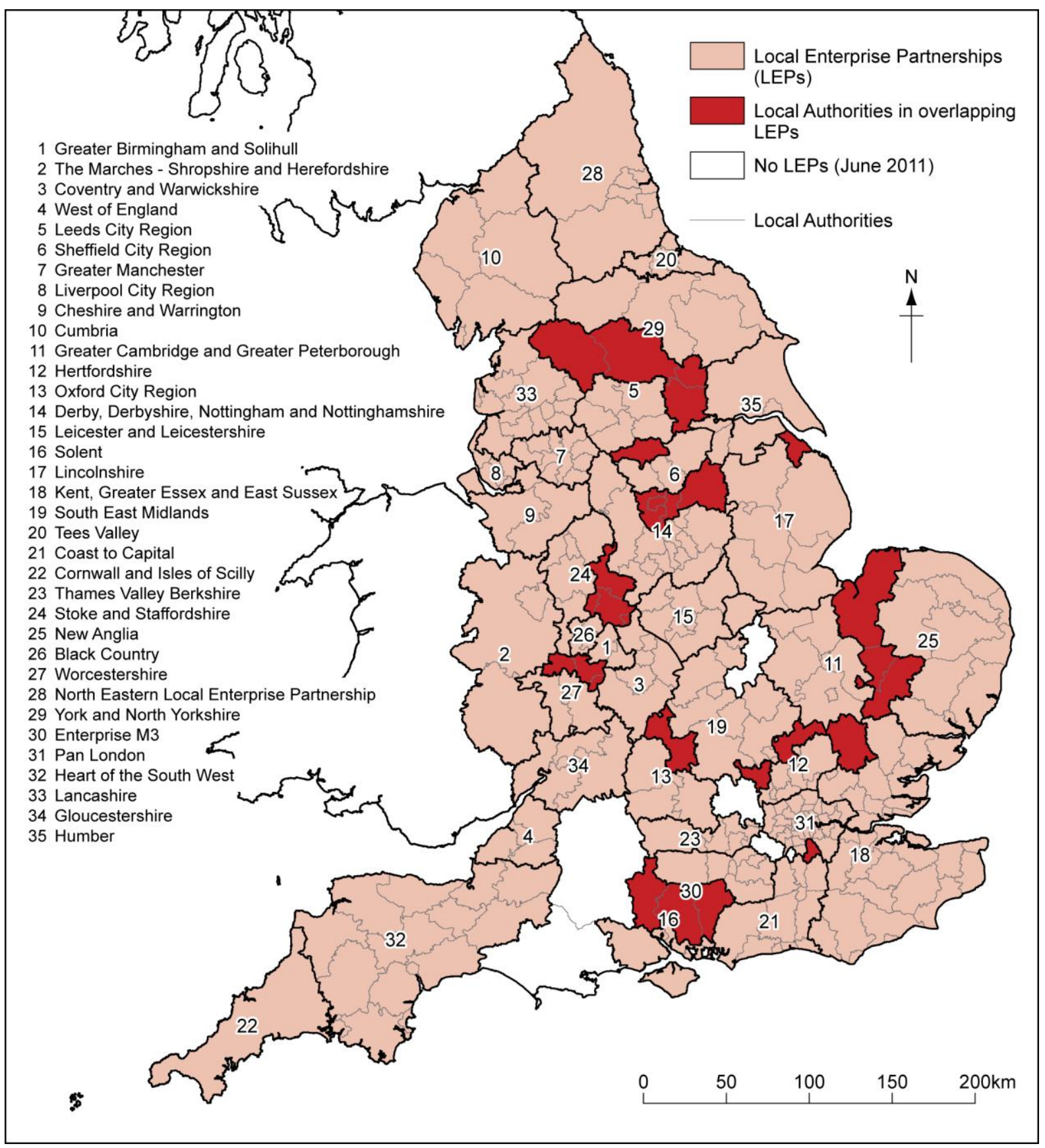

Source: adapted from BIS (2011b) @ Crown Copyright 2011. URN 12/P113A @ C Crown Copyright 2012. An Ordnance Survey/EDINA supplied service.

authority areas were covered by a single LEP with others by more than one. Nevertheless, this new sub-regional geography for economic development was largely based on the existing structure of local and unitary authorities (Figure 2). 
Table 1: Policy aims from the Government Tourism Policy, 2011

\begin{tabular}{|c|c|}
\hline Basic Aims & Headline proposals, to: \\
\hline $\begin{array}{l}\text { Co-fund the most ambitious } \\
\text { marketing campaign ever to attract } \\
\text { visitors in the UK in the years } \\
\text { following } 2012\end{array}$ & $\begin{array}{l}\text { - Modify existing, long-established Tourist Boards to } \\
\text { become smaller, highly focused, industry-led } \\
\text { partnerships between tourism firms and government } \\
\text {...funded through long-term partnership marketing } \\
\text { campaigns } \\
\text { - Broaden the UK tourism offer by creating alternative } \\
\text { destinations which will match London } \\
\text { During } 2012 \text {, to bring together tourism ministers at a } \\
\text { World Summit }\end{array}$ \\
\hline $\begin{array}{l}\text { Increase the proportion of UK } \\
\text { residents who holiday in the UK to } \\
\text { match those who holiday abroad } \\
\text { each year. }\end{array}$ & $\begin{array}{l}\text { - Consult on move to first bank holiday in May } \\
\text { - Work with Highways Agency to ensure Brown Signs as } \\
\text { informative as possible to road users }\end{array}$ \\
\hline $\begin{array}{l}\text { Improve the sector's productivity to } \\
\text { become one of the top } 5 \text { most } \\
\text { efficient and competitive visitor } \\
\text { economies in the world. }\end{array}$ & $\begin{array}{l}\text { - Give industry and consumers responsibility for hotel } \\
\text { 'star rating' quality schemes } \\
\text { - Help to improve staff and management skills across the } \\
\text { entire industry } \\
\text { - Help the industry prepare for changes in technology } \\
\text { - Create an industry task force, led by senior figures from } \\
\text { - Macross the UK, to cut red tape } \\
\text { - } \text { convenient to get } \\
\text { lmprove tourists' first experience of the UK when they } \\
\text { land at our ports or airports }\end{array}$ \\
\hline
\end{tabular}

Source: Abridged from Penrose (2011: 7-10)

\subsection{New Localism and Tourism Administration in England}

The initial effects of these reforms was to erase, at a stroke, the established regional layer of tourism administration in England ( $\mathrm{HI}$ 2010) and to create uncertainty about how the key functions undertaken by RDAs and RTBs in the past, would be conducted in the future (Tourism Alliance 2010, 2011; Janson 2011). This was compounded in three respects. First, during the Comprehensive 
Spending Review of November 2010 (HMT 2010), reductions in the settlements to local authorities were announced; that is, cuts to partners in, and possible financial contributors to, LEPs as well as major actors in existing local-level arrangements for tourism management and development. Tourism is a non-statutory obligation for local authorities; thus, expenditure on this activity came under even greater scrutiny. Second, as part of the same exercise, VisitEngland (VE), the national tourism organisation to which RTBs had faced in the past, had its budget cut by 34\% by 2014/15. However, it was required to minimise cuts to its front-line services while halving its administration budget. As a result, its role was recast as providing 'support for destination management organisations and local businesses, local authorities and enterprise partnerships involved in tourism' (Hunt 2010; VB 2010; VE 2010, undated).

This refocusing previewed the Coalition Government's Tourism Policy which was published by the Minister, John Penrose, in March 2011 (Penrose 2011). The policy had three macro-level aims (Table 1) and it set some ambitious targets for the next decade, with the 2012 Olympics identified as platform from which to launch a sustained period of growth and productivity gains (see also DCMS 2011). Among a series of detailed actions, considerable space was devoted to how new governance arrangements should contribute to change across the board through 'stronger, more focused tourism bodies' (Penrose 2011: 19). State involvement in tourism management, in particular in marketing, was identified as an entirely unacceptable and unaffordable instance of market failure (Penrose 2011: 8). The taxpayer alone should not be expected to pay for marketing for a large and successful sector of the economy (Penrose 2011: 19). As a third complication, 'new industry-led local tourism bodies' were required because (Penrose 2011: 21),

'The problem is that, while there are some notably capable and highly respected local Tourism Bodies (often called Destination Management Organisations, or DMOs, in industry jargon), the industry is clear that there are some which have lost their way too. The best examples tend to work as respected partners with local tourism firms, who are happy to work alongside because they can measure the impact of their local tourism body's marketing activities on their revenues. The worst are expensive talking shops which achieve very little, or 'civic pride' marketing organisations whose campaigns are better at massaging committee members' egos than driving footfall and boosting sales for local tourism attractions.'

However, these ideas were not accompanied by substance, nor was the evidence underpinning this aspect of the new policy presented. For instance, unlike Zach's (2012) analysis of American DMOs, there had been no systematic research on the success factors that drive visitor-oriented innovations in services in order to enhance destination competitiveness. Rather government merely proposed modern, focused and efficient DMOs that will be responsible for management not just marketing, and which would cover functional tourism territories (as defined or identified by visitors), not arbitrary boundaries of RDAs, local authorities or even LEPs (Penrose 2011: 21). As the Prime Minister, David Cameron (2010: n.p.) made clear a year before in his first speech to tourism industry leaders,

'The old Regional Development Agencies put bureaucratic boundaries over natural geography.... Now if areas like this want to work together across those old, centrallyimposed boundaries they can.'

Collaboration between DMOs was encouraged where appropriate. Although the private sector was expected to contribute an ever greater proportion of costs over time (perhaps through sponsorship and marketing) thereby 'weaning the industry off public subsidy' (Penrose 2011: 20), local businesses would be free to join and leave as they wish. Fluid membership was advocated as a 
means to ensure good governance and the wise(st) use of resources (Penrose 2011: 24). Voluntary participation in local partnerships was encouraged because government,

'.... will not create new institutional or bureaucratic structures to make this happen: good Tourism Bodies are already being listened to with influence and respect by Local Authorities and nascent Local Enterprise Partnerships, and more centrally-imposed bureaucracy will not make bad DMOs more influential' (Penrose 2011: 23).

The geographical congruence between DMOs and LEPs may not always be neat. However, partnerships between DMOs and LEPs were seen as vital in positioning the visitor economy within wider economic strategies and, if tourism were to drive enterprise, growth and employment in a local area. In terms of operations, it would be 'for individual Local Enterprise Partnerships and DMOs to develop their own working arrangements, based on their analysis of local conditions, challenges and opportunities' (Penrose 2011: 23). With respect to access to resources, government anticipated that tourism bodies (i.e. DMOs) would act as partners in local authority or LEP bids for funding, for instance to the RGF (Penrose 2011: 25). This was wholly predictable in the sense that local authorities would be major actors in, and contributors to, both DMOs and LEPs. Finally and reflecting this dual stakeholder status, future financial settlements to local authorities would take greater account of the importance of the visitor economy and provide the means by which to match private sector money (Penrose 2011: 25).

For critics, the vagueness and provisionality of the new policy was disconcerting and dangerous. As Ufi Ibrahim (2011: 5), CEO of the British Hospitality Association, complained at the time,

'The government has given very little detail about how they [LEPs] will be structured and financed and how supportive of tourism LEPs will be. Yet tourism is the economic driver of many regions of the country. As a result, it's very difficult to see how effective LEPs will be for hospitality and tourism, and that's a significant risk to the industry's latent potential for regeneration and job creation in precisely those areas of the country where it is most needed.

\section{Making Sense of the Changes in Tourism Administration in England}

Clearly then, the recent change in UK government was followed by a radical shift in the predominant spatial scale and preferred mode of tourism governance in England. There was a move from a strong regional orientation based on active government to a more neo-liberal, locally-based approach in the latest tourism policy. Moreover, this was accompanied by uncertainty in the sector, not least because such reforms were untested and they raised a series of contradictions. Subregional tourism bodies may have been present prior to 2010 but the state, at the regional level, had long held the major strategic roles of co-ordination and development. Similarly, although tourism has been routinely presented as an important facet of economic development in England (BBC 2011; Deloitte and Oxford Economics 2010), the central state was actively attempting to withdraw from its role as a catalyst by reducing its commitments financially and operationally. Tourism was presented by government as an important means for reducing the deficit but its approach was not to continue nor even grow its various roles in tourism administration prior to the 2012 Olympics which it had identified as a watershed for future growth. Finally, LEPs were presented as a conduit for tourism development but it was unclear how those involved in LEPs -as a previously untried vehicle for local economic development- would view tourism; whether LEPs would be be able to forge productive relationships with DMOs (or other local tourism actors) as policy demanded; and if LEPs would 
support (investment in) tourism. In any case, tourism would be competing for resources with the other major forms of economic activity in each LEP territory.

The challenge then, is how to interpret a complex and apparently contradictory situation where central government acknowledged the importance of tourism for rebalancing the economy while seeking to reduce the level of direct public support for it not least by removing the predominant spatial scale of administration. Empirically, these reforms raise two connected research questions that are examined later in this paper, namely: how far does tourism feature on the LEPs' agendas, and how have practitioners at the destination level been making sense of the evolving situation? Conceptually, existing analyses of tourism policy offer only limited clues. After all, the majority of such studies have been conducted during periods of economic growth and rising individual prosperity. This is in stark contrast to the current recessionary conditions, sovereign debt crisis, and the need to reduce public sector deficits. For instance, the relative merits of different types of collaborations, partnerships and other types of organisational arrangements in tourism were debated heavily around a decade ago (Bramwell and Lane 2003; Hall 2008a). In the case of the UK (as well as other Western economies) this was a time when, although it looked for the most effective return on its investment through the so-called 'best value agenda' (Coles 2003), government was nevertheless willing to invest in public sector support for tourism at a comparatively higher level. In fact, arguably the nature of the discourse followed the 'institutional' and 'scalar' turns (Jones 2001) of the New Labour Project. It advocated building stronger, enduring institutions that would overcome the traditional dichotomy between the public and private sector in tourism development, which were increasingly less reliant on the hollowed-out state, and which collectively as a series of sub-regional networks and partnerships contributed to the view of the region as the 'crucible' for economic development (Webb and Collis 2000: 857).

Recasting this argument, seldom, if ever, has there been discussion of the wholesale removal of a particular spatial scale of tourism administration. Jenkins (2000) examined the historical, structural, political and behavioural challenges facing regional tourism organisations in their attempts to survive in New South Wales, Australia and he identified a series of barriers in this regard. For the same state, in a later contribution Dredge and Jenkins (2003a) revealed the tensions between local and regional conceptualisations and portrayals of place. However, both studies pointed to the resilience of the region as an administrative unit. Indeed further recent contributions have demonstrated renewed region-building through tourism, notwithstanding the 'slippery nature' of the concept (Richardson 1978: 25 in Jenkins 2000: 175). For instance, Henrikson and Halkier (2009) investigated the processes in North Jutland (Denmark) by which localized marketing was transformed towards more robust regional tourism policy based on innovation. Prokkola's (2011) work added a further dimension to the mediation of new regional tourism identities across international frontiers. She examined how the European Union has contributed to the functional and imaginary regionalization of North Calotte covering parts of Finland, Sweden, Norway and Russia. Further studies on interest groups and lobbying have drawn attention to attempts to raise the profile of tourism within legislatures and among key decision-makers with a view to consolidating and building on the importance of tourism, usually as a driver of (even further) economic development. In such conditions, audiences are favourably predisposed to such messages, even if they are not always attentive (Tyler and Dinan 2001a, 2001b; McGhee et al 2006). Hardly, if at all, have they examined how the case for greater public sector support for tourism is made at a time when public spending is dramatically shrinking and/or the nation-state is looking to significantly reduce its role as a mediator or facilitator of tourism. 
Finally in this regard, many empirical analyses have routinely identified shortcomings, inconsistencies or gaps in the apparatus of tourism policy and planning. Variously and depending on their scope, syntheses of this work have not surprisingly adopted a normative focus on how to improve provision, implementation and further strengthen the architecture of public sector support for tourism (Dredge and Jenkins 2007; Edgell et al 2008; Murphy and Murphy 2008, Hall 2010). Arguably then, a great many studies of tourism policy have followed what Snowden (2005: 47) has termed the dominant ontology of management science; that is, they have assumed that order is the preferred condition, that the world may be understood by relatively simple cause-and-effect relationships, learning from the past is key to the present, and the future can be planned on the basis of desired outcomes. For example, in their account of tourism policy and planning Edgell et al (2008: 325) identified a series of future world tourism issues, including safety and security, health issues, natural disasters and climate change. They adopted just such a reductionist approach and argue that the "key to prospective growth of tourism will be to ensure that careful planning and effective policies are in place'. In other words, 'tourism policy will help to guide planning functions and political goals in response to new trends as tourism grows' (Edgell et al 2008: 325-326).

In contrast, very few have adopted story-telling (cf. Dredge and Jenkins 2011) or other sense-making approaches like -but not restricted to- Cynefin that are more common in mainstream management studies. As a counterpoint, scholars of business strategy have argued that, instead of order, these are 'post-normal times' in which a more traditional scientific approach to data collection, reasoning and policy-making is no longer plausible (Ringland 2010: 634). Knowledge production is messy, positioned and often under urgent time pressures. This renders 'facts' inherently contestable; it requires decisions where not all factors are knowable or known; and behaviour is not always rational as a consequence (see also Law 2004). As such, it makes more sense to manage on the basis of uncertainty (Snowden and Boone 2007) which is precisely the situation faced by the tourism sector in England as a result of the Coalition Government's reforms. One potential approach, among several recent advances in organisational studies (Michaels 2009; Browning and Boudes 2005) that may assist in the interpretation of public sector support for tourism, its future development and its ability to contribute to other policy goals (Table 1), is the 'Cynefin Framework' (Snowden 2002, 2005; Kurtz and Snowden 2003). To date, this has been variously applied to interpret approaches to disaster recovery in business (Antunes et al 2011), information brokerage (Michaels 2009), future developments in education (Hiscock 2004; Fensham 2011), food security (Shepherd et al 2006), managing risks (French et al 2011; Grotan et al 2011), knowledge production in healthcare (Mark 2006) and medicine (Sturmberg and Martin 2008) but not as yet travel and tourism.

Cynefin is based on the proposition that there are three ontologies within management which are connected: complexity, chaos and order. Chaos is often confused as dichotomously related to the state of order which represents structure and predictability. In fact, as Snowden (2005) argues, the three are connected (see Figure 3). Chaos in the sense of total and absolute turbulence is to be avoided. Between these two states sits complexity in which systems are 'retrospectively coherent; that is to say that we can see the pattern of causality with the benefits of hindsight' (Snowden 2005: 48). Each state requires a different approach to analysis, intervention and management; however, it is through the identification of movement between the states and how this is experienced that the Cynefin Framework represents a distinctive approach to making sense of strategy and policy. 


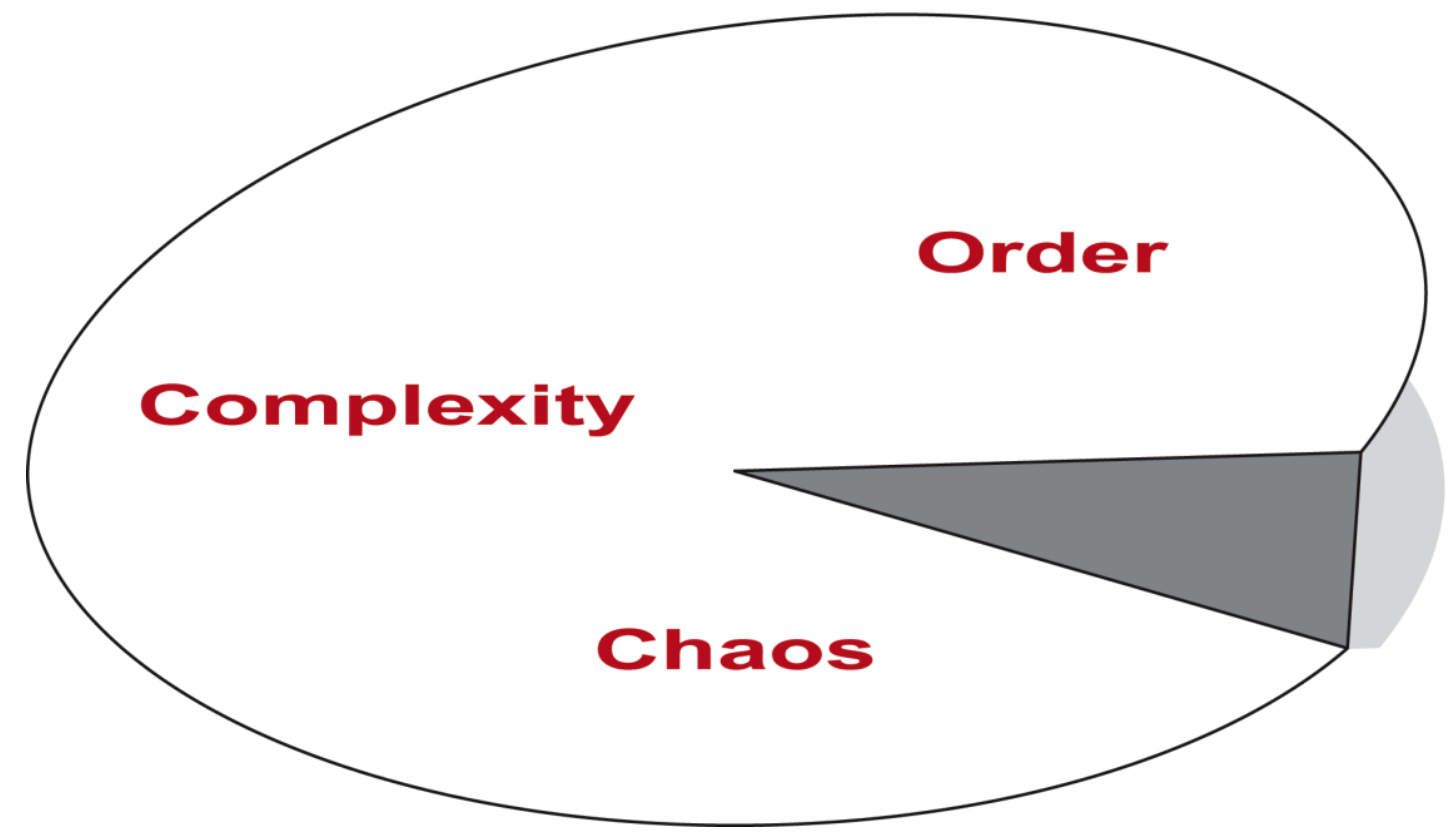

Source: adapted from Snowden (2005)

Planned movement may not result in anticipated outcomes and so it is pertinent to question how change is perceived and made sense of within organisational settings. For instance, it is possible to shift from order to chaos where there is a catastrophic failure of the system ('falling off the cliff edge'). This need not be perceived as exclusively negative. It may also create space for radical innovations which may in time lead to beneficial outcomes. Similarly, shifts from order to complexity may be regarded as helpful since they prevent complacency and reduce the risks of catastrophic failure (Snowden 2005: 48). As Browning and Boudes (2005: 39) observe, one of the ironies of bureaucratic control is that it might suggest order but it can sometimes produce results the opposite of which were intended.

Based on a Welsh word for multiple affiliations, the Cynefin Framework was developed in action research. It recognises that human interactions are based on multiple experiences, "both through the direct influence of personal experience and through collective experience expressed as stories' (Kurtz and Snowden 2003: 467). As a tool, Cynefin can be used to identify individual or collective assessments of the current state of affairs and possible future trajectories on single issues or programmes of activity in government and industry (Mark 2006; Shepherd et al 2006). Kurtz and Snowden (2003: 468) argue that Cynefin is a sense-making, not categorization framework and this is an important point to which we shall return in Section Six. At first inspection, though, this is logical in the sense that the framework embraces messiness and complexity (as much as order and structure) and hence it is inappropriate to expect a perfect fit between the categorizations (Tables 2 and 3, Figure 4) and the empirical world. Still, it is important to point to this distinction because Cynefin's 'value is not so much in logical arguments or empirical verifications as in its effect on the 
Figure 4: The Cynefin Framework

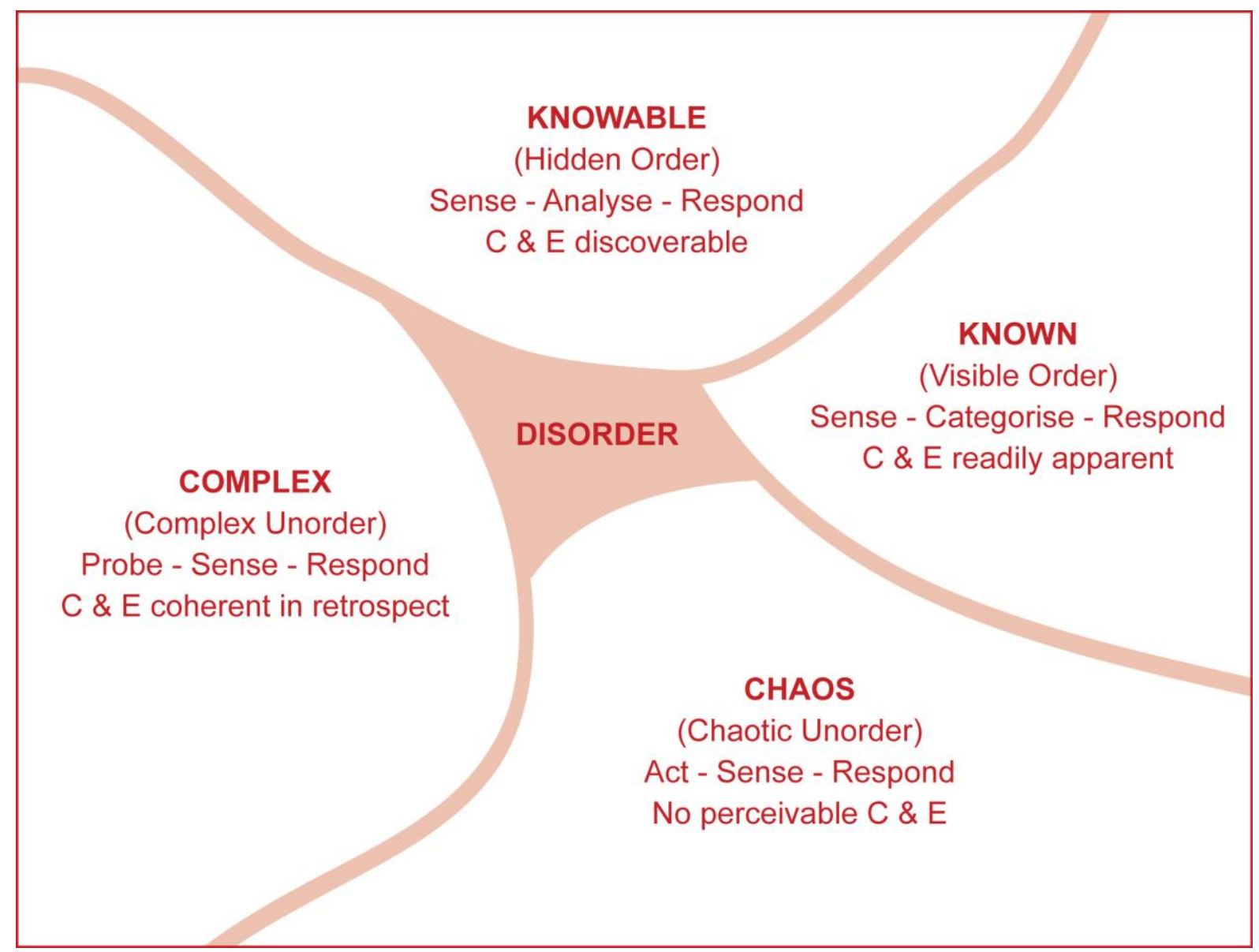

Adapted from: Kurtz and Snowden (2003), Snowden (2005) and French (2010), C \& E = cause and effect

sense-making and decision-making capabilities of those who use it'. It enables stakeholders to reveal their positions to others, to develop shared understandings from which to move forward, and hence enhance decision-making capabilities.

One of the most distinctive aspects of Cynefin is its four major domains which are set out in Table 2 (see also Kurtz and Snowden 2003; Snowden 2005; Shepherd et al 2006, Michaels 2009). Two domains are based on order. Cause-and-effect are self-evident in Visible (i.e. Known) Order which exhibits many of the hallmarks of classical rational management. In contrast, Hidden (i.e. Knowable) Order refers to latent cause-and-effect relationships that can be uncovered and capitalised upon through expert analysis and knowledge. Two domains are grounded in what Kurtz and Snowden (2003: 465) refer to as 'un-order' which is 'not the lack of order, but a different kind of order' that requires entirely different thinking to identify approaches moving forward. For Snowden (2005: 50), the nature of un-ordered systems means that they need to be changed by either managing or creating patterns. According to Michaels (2009: 1005), the strengths of Cynefin are that it challenges the assumptions that human behaviour is rationality or completely intentional, and that 'causality is not discernible in all circumstances'. Perhaps nowhere is this more so than Chaotic Unorder where order is not even retrospectively coherent. The system has been disrupted (perhaps as a result of 
Table 2: Features of the four Cynefin 'domains'

\begin{tabular}{|c|c|c|c|c|}
\hline State: & Chaos & Complexity & Knowable & Known \\
\hline Domain: & Chaotic Un-order & Complex Un-order & Hidden Order & Visible Order \\
\hline Decision Model: & Act-sense-respond & Probe-sense-respond & Sense-analyse-respond & Sense-categorise-respond \\
\hline Cause and effect: & Not perceivable & $\begin{array}{l}\text { Coherent in retrospect; } \\
\text { do not repeat }\end{array}$ & $\begin{array}{c}\text { Separated over time and } \\
\text { space }\end{array}$ & $\begin{array}{c}\text { Repeatable, perceivable, } \\
\text { predictable }\end{array}$ \\
\hline Practice: & Novel practice & Worst practice & Good practice & Best practice \\
\hline Leitmotif: & \multicolumn{2}{|c|}{ Avoidance of failure } & \multicolumn{2}{|c|}{ Imitation of success } \\
\hline Approach: & Stability-focused intervention & Pattern Management & Analytical/reductionist & Legitimate best practice \\
\hline Technologies: & Enactment tools & Perspective filters & Scenario planning & $\begin{array}{c}\text { Standard operating } \\
\text { procedures }\end{array}$ \\
\hline Mode: & Crisis management & Complex adaptive systems & Systems thinking & Process re-engineering \\
\hline Nature of knowing: & \multicolumn{2}{|c|}{$\begin{array}{l}\text { Emergent, experimental, uncertain; } \\
\text { Knowledge of conditions, not outcomes }\end{array}$} & \multicolumn{2}{|c|}{$\begin{array}{l}\text { Empirical, hypothesis-based, } \\
\text { objective validation or refutation }\end{array}$} \\
\hline Brokerage style: & $\begin{array}{c}\text { Opportunistic } \\
\text { entrepreneurship }\end{array}$ & Engage & Consult & Inform \\
\hline Mediation style: & Exploit serendipity & $\begin{array}{l}\text { Expose multiple } \\
\text { perspectives }\end{array}$ & Facilitate relationships & Expedite transmission \\
\hline Nature: & \multicolumn{2}{|c|}{ Exploration } & \multicolumn{2}{|c|}{ Exploitation } \\
\hline
\end{tabular}

Sources: adapted from Kurtz and Snowden (2003), Snowden (2005) and Michaels (2009) 
Table 3: Types of Possible Cynefin Movements

\begin{tabular}{|c|c|c|c|}
\hline Mode & From & To & Notes \\
\hline Collapse & Known & Chaos & $\begin{array}{l}\text { Associated with catastrophic collapse when } \\
\text { dynamics of system change. }\end{array}$ \\
\hline Imposition & Chaos & Known & $\begin{array}{l}\text { Imposition of order from chaos. Order may } \\
\text { introduce rigidity. }\end{array}$ \\
\hline Incremental improvement & Knowable & Knowable & $\begin{array}{l}\text { via Known, oscillating. Commonly accepted } \\
\text { approach to development. }\end{array}$ \\
\hline Exploration & Knowable & Complex & $\begin{array}{l}\text { Selectively. Opening possibilities without } \\
\text { removing central control without total } \\
\text { disruption. Trust required. }\end{array}$ \\
\hline Just-in-time transfer & Complex & Knowable & $\begin{array}{l}\text { Selectively. Selective choice of stable patterns } \\
\text { for ordered representation. }\end{array}$ \\
\hline Swarming & Chaotic & Knowable & $\begin{array}{l}\text { via Complex. Chaotic to complex movement } \\
\text { emergent - complex to knowable selectively. } \\
\text { New patterns in first stage stabilised in second. }\end{array}$ \\
\hline Divergence-Convergence & Complex & Complex & $\begin{array}{l}\text { via Chaotic, repeatedly. Active disruption of a } \\
\text { complex system. }\end{array}$ \\
\hline Entrainment Breaking & Knowable & Complex & $\begin{array}{l}\text { via Chaotic, periodically. Stimulates new } \\
\text { complex systems as system rebounds. Used to } \\
\text { create new sources and structures for } \\
\text { decision-making. }\end{array}$ \\
\hline Liberation & Known & Knowable & $\begin{array}{l}\text { via Complex, periodically. Departure from } \\
\text { ordered to embrace external and internal } \\
\text { inputs to stimulate new interactions to allow } \\
\text { to move forward. }\end{array}$ \\
\hline Immunization & Known & Known & $\begin{array}{l}\text { via Chaos, temporarily. Chaos is 'visited' } \\
\text { temporarily, 'shakes things up' to cause } \\
\text { reflection but not to destabilise entire system. }\end{array}$ \\
\hline
\end{tabular}

Source: abridged from Kurtz and Snowden (2003: 475-479) 
catastrophic failure) and the 'rules of the game' are not apparent. Instead, actors respond to establish themes and thereby impose (a degree of) order and emergent patterns from which to progress. Finally, in Complex Un-order, social relations among actors produce an emergent and unfolding situation. The environment is probed to sense what organisational patterns emerge, which to stabilize or disrupt. Management occurs in this domain not on the basis of predictability or desirability but on attractors around which patterns form (Snowden 2005: 50). In this respect, it is possible retrospectively to identify order and outcomes.

A fuller exposition of the dimensions or the logic underpinning them is not possible here and in one sense it is not entirely necessary. While it may be tempting to regard the Cynefin domains as a twoby-two matrix in which to simply categorise behaviour, this was not the intention (Snowden 2005); hence the way Figure 4 is drafted and as the state of entire disorder at the centre connotes. No domain is more or less desirable than another and there are no implied axes. There is no preferred direction of travel but one of the goals of applying the framework is to increase awareness of movement to induce sustainable change. Interestingly, Complex and Knowable systems have particular merits in so far as Known systems have vulnerabilities in times of uncertainty (Kurtz and Snowden 2003: 475). The purpose then, is not to encourage the mapping of as much data as possible in order to identify a single domain that best fits the current case. Rather, it is to discover what is happening, what may happen (to prevent it if necessary), and how to increase certainty by 'changing the boundary conditions so that unknowable events are less likely to occur' (Snowden 2005: 48). In practice, each domain and its boundaries is defined by multiple narratives which are socially-constructed and commonly understood within group settings (Snowden 2005: 49). The important features are how boundaries between the various conditions are perceived, how they have been transgressed, and how they are to be crossed to arrive at the desired end point. To cross boundaries requires new resource arrangements, leadership styles and ways of understanding. Ten trajectories between dimensions were initially identified in the empirical work underpinning the Cynefin Framework based on how an array of organisational actors predominantly made sense of change (Table 3). Of course, these are reductionist devices, they represent simplifications of complex realities, and originally they were devised to consider change within (different parts of) organisational settings. However, as hinted in the previous section, they offer significant potential to interpret the changes taking place in tourism governance and administration in England and how they are being experienced by those who are intended to implement them. In the next section we turn to discuss the methods used in the empirical research underpinning this paper. Although Cynefin was originally developed through action research and its pioneers have used a wide range of methods to elicit narratives of experiences of change, recent applications of the framework have employed a range of mixed methods strategies, routinely employing secondary data and interviews. It is on those precedents that this research is based.

\section{Methods}

A two-stage programme of empirical research was devised to address the two research questions. The first stage explored how tourism featured among LEPs while the second examined how 'destination groups' have been making sense of the evolving situation. Data were collected in May and June 2011: that is, within a year of the announcement in 2010 of the disbanding (and final closure in 2012) of the RDAs (Cable and Pickles 2010); six months of the CSR which presented the detail of the public sector funding cuts (HMT 2010); and half a year of the closing date for applications to establish LEPs (Cable and Pickles 2010). A mixed methods approach was utilised in the first stage. A content analysis was conducted of the proposal document for each LEP as well as their web sites (where they existed) for references to tourism. This was intended as a proxy for the 
Figure 5: Current work priorities for destination groups

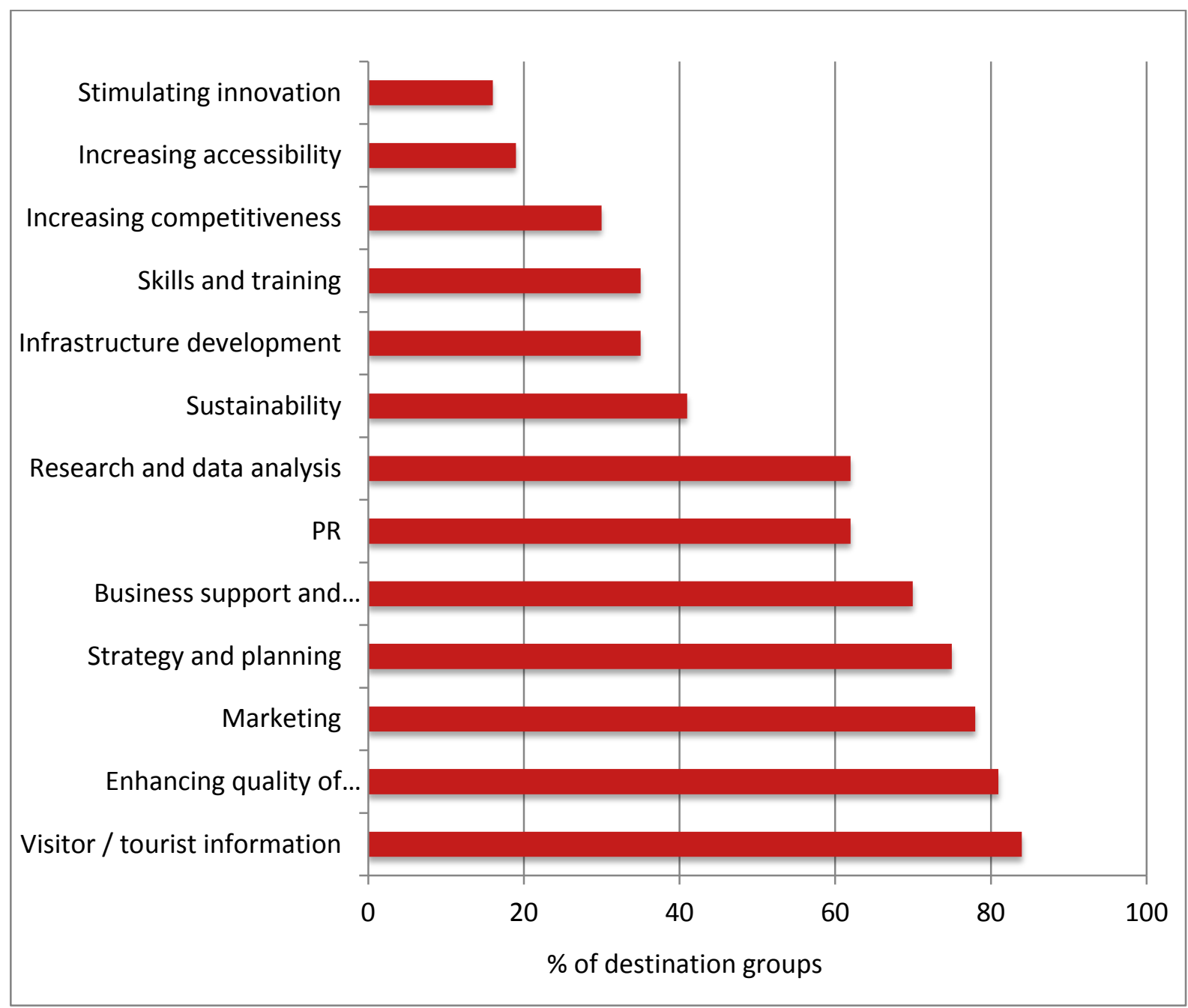

Source: authors, questionnaire survey

importance of tourism to LEPs. Categories were identified with respect to how tourism was portrayed and basic, indicative frequencies were calculated (Hall and Valentin 2005). These results were used as a basis for a short online questionnaire comprising 12 questions which was sent to all 35 LEPs approved at the time of the research with the aim of establishing how they perceived their role/s in relation to the tourism sector. Responses were received from 15 (i.e. 43\%) LEPs and short, follow-up interviews were conducted with officers in four LEPs to confirm our emergent findings.

In the second stage, views in destination groups were gathered. As noted above, during the previous decade the concept of destination management organisations had gathered some traction in England and sub-regional bodies were established variously calling themselves 'destinations', 'destination management organisations', 'destination marketing partnerships' (DMPs) or 'tourism partnerships' (TPs). Significantly, these were precisely the type of arrangements that the Coalition Government expected to interface with LEPs in the co-ordination of economic development and 
resource allocation. According to Destination Performance UK (DP:UK n.d), there were 86 such organisations operating in 2011 in England (n.b. there are 257 separate local and unitary authorities; CLG 2011). Each was sent a questionnaire to be completed by the most senior manager. For this expert group, the 19 questions explored their current and future functional roles; governance arrangements and budget plans; the level of their engagement with the local LEP(s); and the extent to which they perceived they are able to deliver on VE's Strategic Framework. Responses were received from 37 destination groups (43\%) and short follow-up interviews were conducted with 16 $(19 \%)$ in order to elaborate the data generated by the questionnaire. Average staffing levels were 9.0 FTEs (full-time equivalent posts) and the typical functions (i.e. conducted by over $50 \%$ ) were to: provide visitor information; improve quality of the product offers; marketing; strategy and planning, business support and advice; PR; and research and data analysis (Figure 5). Put differently, these are many of the functions envisaged by government of well-managed and well-positioned DMOs (Penrose 2011).

\section{Results}

\subsection{Local Enterprise Partnerships (LEPs) and Tourism}

Tourism featured in the texts produced by 33 of the 35 LEPs. Only two (Thames Valley and Lancashire) did not refer to it (Figure 6). Based on a reading of the documentation and the nature of their responses to the online survey, seven LEPs portrayed tourism as a key priority. Among these were areas where tourism has been a long-standing mainstay of society and economy -such as Cornwall and the Isles of Scilly and the West of England (incorporating the city of Bath)- and areas in which there has been significant recent place marketing based on tourism (Figure 5). Of the latter were the former European City of Culture, Liverpool, as well as York and North Yorkshire - including 'Heartbeat Country' (Mordue 1999) and several other popular destinations from popular TV programmes (Beeton 2008). 26 LEPs variously articulated more modest interests in tourism (Figure 6). Within this group were some areas in which we may have reasonably expected tourism to have featured more prominently due to the strength of the visitor economy both in the past and projected into the future. The Heart of the South West (Devon and Somerset), Cumbria as the home of the Lake District, and Oxford City Region were examples of the former while Pan London was likely to benefit most from the 2012 Olympic Games (CMSC 2007).

At the time of the research there were five discrete areas of England for which there was no LEP coverage (Figure 2). Most notable among these perhaps was a contiguous zone covering Dorset and Wiltshire. Both counties have strong rural tourism offers while Dorset is home to the Jurassic Coast World Heritage Site and the major coastal resort destination of Bournemouth. LEPs covering these areas were announced in July 2011 after the empirical research was concluded but it is notable that prominent destinations were among the latest to have a LEP approved. 
Figure 6: The status of tourism within LEP documentation (June 2011).

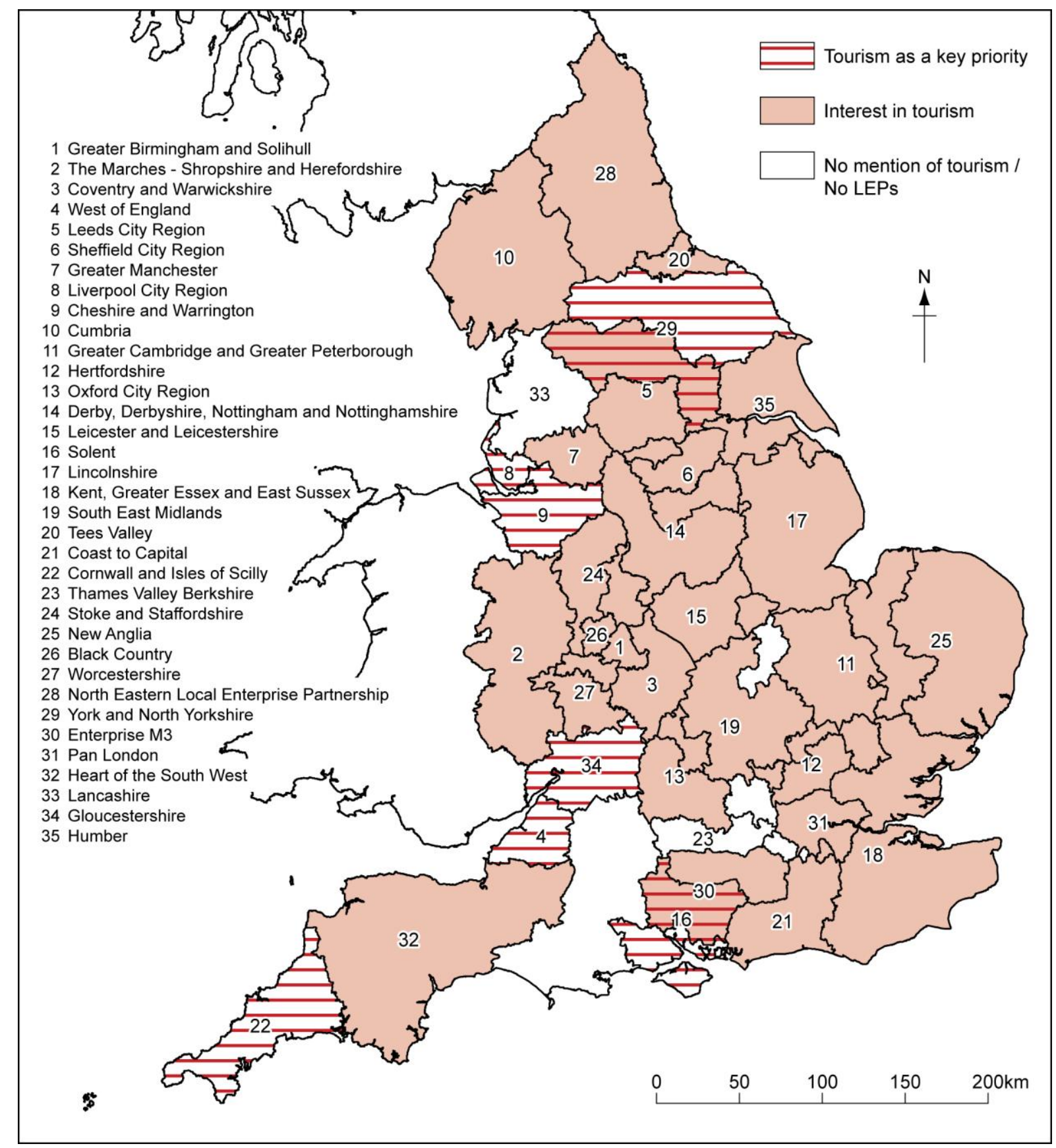

Source: data authors, map (c Crown Copyright 2011. URN 12/P113A @ Crown Copyright 2012. An Ordnance Survey/EDINA supplied service. 
Figure 7: The frequency of tourism-related themes in LEP documentation.

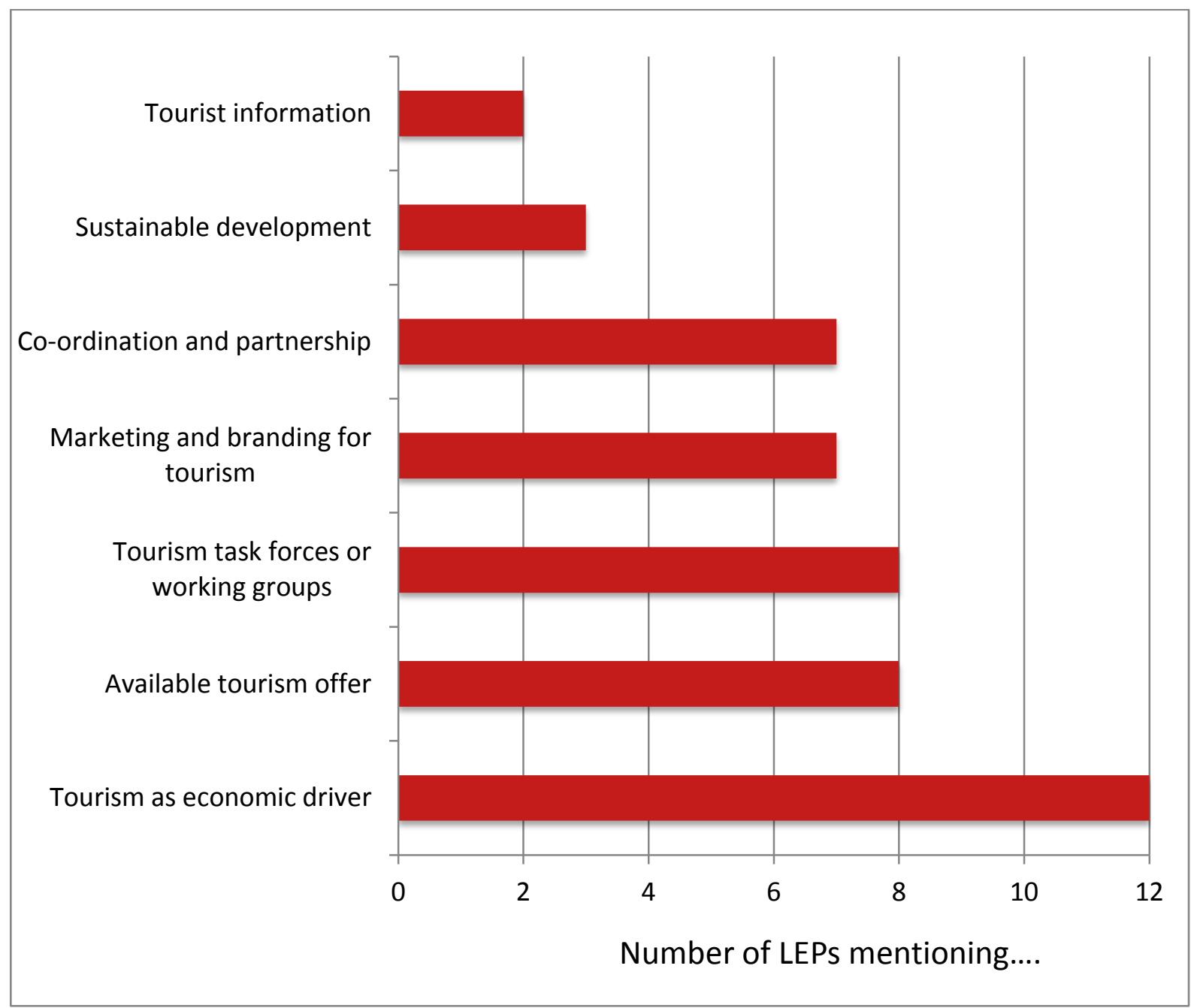

Source: authors

In twelve parts of England, there was overlap among LEPs. Interestingly, in all but one case (Lancashire overlapping with York and North Yorkshire), the overlaps existed among LEPs that expressed no more than moderate interest in tourism. In other words, there was no overlap between the seven LEPs that identified tourism as a key priority. There were, though, two sets of such LEPs that are adjacent to one another: Cheshire and Warrington (the former home of the Northwest RDA) with Liverpool; and West of England with Gloucestershire. These may collaborate in the manner anticipated by government policy to accelerate tourism development through collective action.

Finally in this regard, there were some notable differences in the way in which the sub-regions of former RDAs portrayed tourism. For instance, within the Northwest RDA area (Figure 1, Figure 6), tourism was a priority for Cheshire and Warrington as well as Liverpool, but it was not mentioned by Lancashire, while Greater Manchester and Cumbria expressed a moderate level of interest. The 
South West of England has long been one of the major destinations for inbound and domestic visitors in the UK (Shaw et al 1998). In the past its RDA (SWRDA) has led on behalf of the other English regions in the implementation of the DCMS agenda, while its RTB (Southwest Tourism) pioneered approaches to sustainable tourism management and regional brand identities (Coles 2008). For just three of the SWRDA sub regions (Cornwall and the Isles of Scilly, West of England and Gloucestershire) tourism was identified as a priority, tourism was only mentioned by two (Devon and Somerset, the Heart of the South West) and -as noted above- two (Wiltshire and Dorset) had no LEP coverage.

From a closer reading of the LEP texts, several themes emerged with respect to how tourism was presented and the role it may play in the future of the areas covered by the LEPs (Figure 7). Most importantly, by virtue of the frequency of mentions (not word count), was the theme of 'tourism as an economic driver' ( $n=12$ mentions). This was not especially surprising because it is entirely consistent with the raison d'être of LEPs (see Section 2). Tourism was described as 'a main driver for economic development' in The Marches (2010: 4, see also Figures 1 and 2) while New Anglia (2010) viewed tourism as a growth sector. Other LEPs pointed to the possibilities to increase employment (Coast to Capital; Cheshire and Warrington; Sheffield City Region), the economy (Birmingham and Solihull) and Gross Value Added (GVA, Cheshire and Warrington). 'Specific aims for tourism' were variously articulated by six LEPs. These included: increasing visitor spend (West of England); length of stay (Coventry and Warwickshire); visitor numbers (Stoke and Staffordshire); and enhancing sustainability (Coast and Capital; Cornwall and the Isles of Scilly; West of England).

Several mechanisms were proposed by which to boost productivity and competitiveness. 'Marketing and branding for tourism' was, somewhat predictably, a function explicitly proposed by seven LEPs. Ambitions varied but hyperbole was evident. Birmingham and Solihull (2010: 29) proposed to adopt an intermestic approach (Hall 2005b) by projecting their locality on the international stage 'to create a global brand' while two LEPs (Greater Manchester; D2N2) advocated using the so-called 'attack brands' at their disposal (Manchester; Visit Peak District and Derbyshire DMP respectively). Customer awareness in a different context was mentioned by two LEPs (Cumbria; Coventry and Warwickshire) for whom it is important to enhance the 'provision of tourism information'. Both extolled the virtues of higher quality and more integrated information for visitors. Solent LEP argued it could enhance competitiveness by providing 'a package of support to develop a growth hub which could include skills investment, tourism, business support and enterprise, and release of site assets'. Enterprise M3 reported it would aim to attract inward investment and encourage green infrastructure in tourism while two LEPs offered the prospect of contributing to tourism proposals and strategies relating to their areas (Coventry and Warwickshire; Greater Manchester).

Leadership roles were mentioned by 11 LEPs in two other overlapping respects. Eight LEPs had set up or intended to establish task forces or working parties on tourism in their area, although little specific detail was provided as to what their likely remit or focus would be. In a similar vein, various roles of 'co-ordination, co-operation and partnership' for tourism were mentioned by seven LEPs. These ranged from establishing and facilitating networks in the LEP area (Birmingham and Solihull; Cumbria) to York and North Yorkshire's (2010: 8) desire to look beyond its boundaries because 'there are mutual interests on collaboration on tourism across all [LEPs] in Yorkshire'. Others (D2N2; West of England) mentioned the need to co-ordinate with the national tourism organisations, VisitEngland and VisitBritain. Indeed, somewhat unexpectedly Sheffield City Region's proposal (SCR, 2010: 14) practically anticipated future central government policy by expressing a desire, 
'to see oversight of strategic tourism priorities and investment decisions devolved to the SCR LEP as appropriate to our City Region .... We see the role of the private sector in tourism as key .... Through the SCR LEP we will make a strong contribution to the Government's national tourism strategy and the objective of increasing domestic tourism spend in the UK. We also want to see strategic economic funds (e.g. the Regional Growth Fund) opened up to support activities that will help to support businesses in the tourism industry and contribute to the overall economic growth of the SCR.'

When asked for their opinions on how clear they thought the landscape for tourism policy was in their area at the present time, for $60 \%$ of LEPs the picture was 'unclear', $30 \%$ were unsure and only $10 \%$ perceived it as 'clear'. Lack of clarity was related to uncertainty over budgets, resources and finances, and hence what activity might be possible in the future. $78 \%$ of LEPs that responded noted they had not yet set a budget for 2011/12, although of the $22 \%$ that had, there was provision for tourism (but we were unable to determine the level of it). Budget delays represented an important impediment to activity. As one LEP representative reported, work could not commence on tourism (or any other sector of economic activity) because 'we still have no budgets in place, so until that is clarified we cannot commit to any area of work'. Another offered a prognosis:

'The RDAs pulling out of tourism means that a large amount of money for tourism has just disappeared. Currently there is only the local authority money left and they are undergoing drastic cuts... The private sector has a willingness to do something... it remains to be seen what VisitEngland can do.... There is a major shake-down at the moment and it would probably take about two years before things become clear for tourism [in our area].'

Clearly arrangements were in flux but local authorities were perceived by at least one LEP as being a principal source of their future funding. Put another way, local authorities were expected to play a major role in, and provide a significant financial stake for, the establishment of LEPs covering their territories at a time when settlements from government had declined and they were also expected to continue funding DMOs (see also below). Notwithstanding constraints on the availability of capital, one particular approach used by several LEPs was to undertake preparatory work ahead of the eventual budgetary outcome. Typical of this, as one interviewee noted:

'We are engaging with tourism [i.e. destination] groups and asking them to tell us what their main problems are and working out what we can do to help e.g. transport provision. Then this will depend on the funding; it all comes down to funding - how many staff we can employ and what we can do.'

Another interviewee from a LEP offered the prospect that attitudes to tourism may in fact change over time but it was for tourism bodies and actors to make the case for its importance and hence support: 
Table 4: Destination groups' experiences of change

\begin{tabular}{|l|r|r|}
\hline In the past 12 months have encountered.... & $n$ \\
\hline Changes in the way the organisation is composed or run & 29 & 83 \\
\hline Changes in governance arrangements & 15 & 54 \\
Reorientation of work priorities & 13 & 46 \\
Changes in membership & 7 & 25 \\
Changes in geographical remit & 7 & 25 \\
\hline Staff increases & 2 & 6 \\
Staff losses & 18 & 53 \\
Steady state staffing & 14 & 41 \\
\hline
\end{tabular}

Source: authors, questionnaire survey, $\mathrm{n}$ refers to valid responses

'We are trying to consult with people....We are not doing anything about tourism at the moment. We may be open to doing something in the future, but we need to be convinced locally that we will be able to make a difference.'

\subsection{Destination groups in the new policy climate}

Turbulence was also highly evident among the destination groups (Table 4). 83\% of respondents had encountered change in the past year, in particular in governance arrangements $(54 \%)$ and in a rebalancing of their work priorities (46\%). While the former referred to how they faced both local authorities and RDAs in the past, responses on the latter embodied the need for such groups to achieve more return on (their mainly public) investment than previously. Among all destination groups, the public sector was the main source of funding, while just $44 \%$ and $29 \%$ respectively claimed that private monies (i.e. membership fees, subscriptions, advertising etc) and commercial activity (i.e. commissions or direct sales to visitors) were also significant sources also. Two-thirds (67.6\%) had experienced reductions from local authorities, and there was not compelling evidence of private capital filling the gap as current policy anticipated (Figure 8). Slightly more groups noted increases $(21 \%)$ than decreases $(18 \%)$ in funding from private sources. Conversely, significantly more groups reported reductions $(40 \%)$ rather than increases $(28 \%)$ in commercial activity within a comparatively more volatile revenue stream. Doubts were raised in interview responses as to when, or indeed whether, private funding would replace public funding:

'There has been a change in the last six months towards more private sector involvement and the private sector becoming more proactive.....But there is a long way to go before private sector will give as much, or more resources and input than the public sector'. 
Figure 8: Reported changes in general funding sources in the past year (May 2010-11)

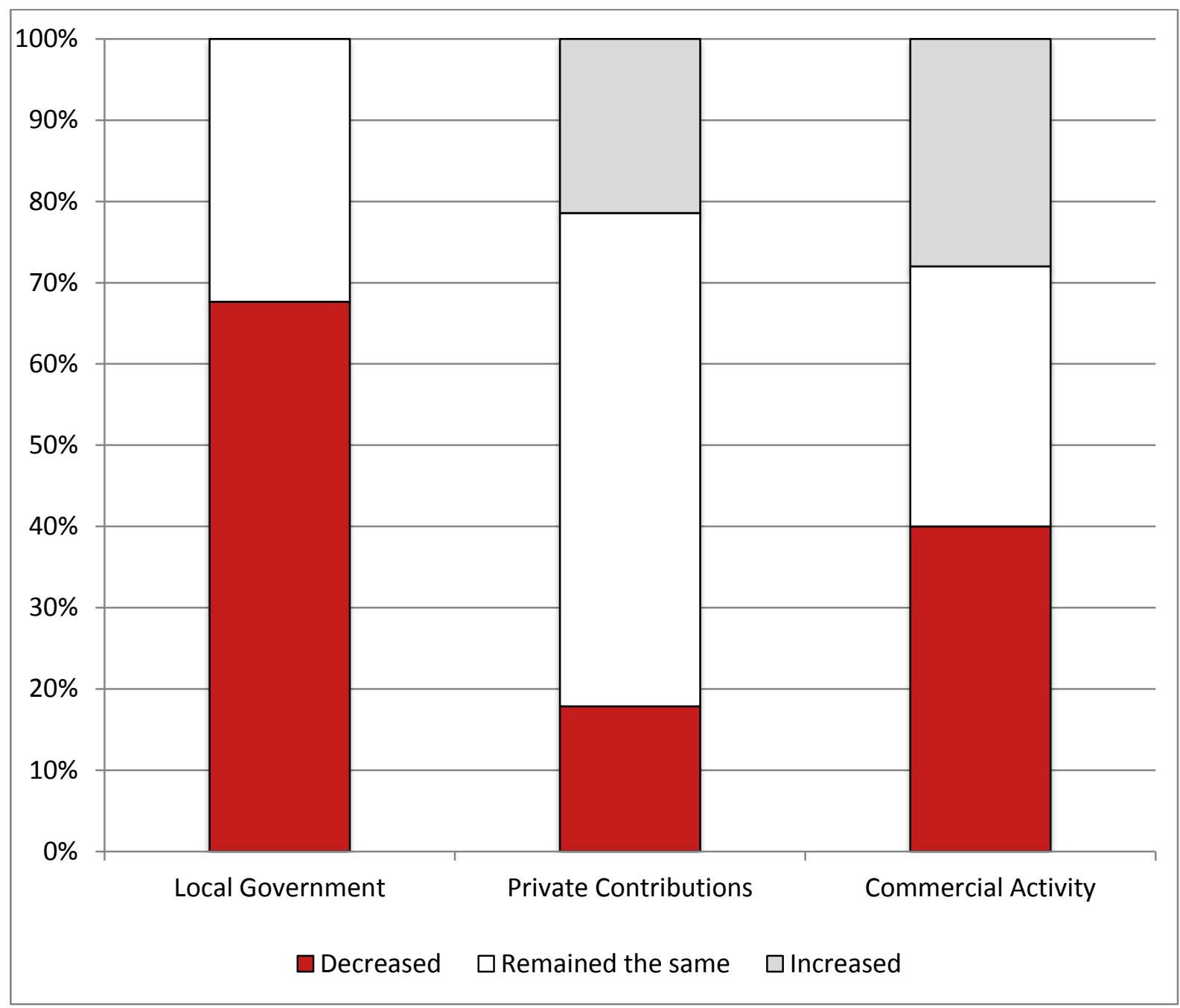

Source: authors, questionnaire survey

Unsurprisingly then, cuts in public spending impacted on destination groups. The magnitude of recent change was noted by several interviewees, for instance:

'I have been in my position for eight years .... it went from money is no object, to government squeezes [during the previous administration] to local funding ending. The change has all happened in the last year though.'

Just over a half (54\%) of destination groups reported staff losses. Managerial capacity and expertise had been eroded as a result of basic approaches to cutting costs to compensate for reduced settlements from central government. As one interview noted, 'a lot of professionals are leaving the sector. There is a brain drain. People are taking early retirement or redundancy packages'. Another reported a mis-deployment of human resources such that 'there is also less time to look strategically 
[as new policy requires] as a lot of time from senior people is focussed on hands-on issues'. One case pointed to the threat posed to local partnership working by the fragmented nature of budget cuts, with individual local authorities making their own spending decisions independently without recourse to partner local authorities (as policy suggests should be the case). As one officer from a team of two Full-time Equivalent staff observed,

'from three neighbouring councils, two now have no tourism staff and one is about to lose theirs [sic] .... so we are the only tourism department left in the area really'.

Various reasons were cited why the private sector had to date failed to fill the funding gap, including the predominance of small enterprises in the tourism sector, public or third sector (i.e. not-forprofit) ownership of several large attractions, and a general unwillingness to pay for services that had traditionally been perceived as the state's contribution to the sector. As one interviewee argued,

'DMOs seem not to be working as a model unless funding is available through other means than membership fees; with the trade reluctant to pay for initiatives traditionally funded through local government, it's unclear how things will pan out.'

As the typical functions undertaken by destination groups demonstrate (Figure 5), 'the public sector in tourism is very important in bringing people together', but for others this array of services was a major reason why the private sector would not fill the gap on its own. Another interviewee argued,

'There is only so much the private sector can do. It's a issue of resources- can the private sector fill the gap? The answer is no, they can't. Should the private sector be a key contributing partner of resources-yes. But there needs to be a connection between the money they put in and the benefit they get out e.g. an increase in numbers of visitors and visitor spend. If it isn't regarded as investment it affectively becomes a tax for them. For the private businesses it is all about the bottom line. There needs to be evidence of the connection between contribution and results. The moment it is not seen as an investment is the moment we are doomed.'

What is more, the private sector should not be expected to fill the gap on its own, nor is it desirable for it so to do:

'On the leadership side, the sector is mainly SMEs. I can't think of an example where a large destination in England is totally run by private sector leadership. Almost all are publicly-led and there needs to be this public leadership and a sense of direction to ensure the buy-in of the private sector. When it is the private sector alone they very quickly enter into the sphere of the public sector, for instance planning. So collaboration is key - they have to do it together. Public leadership has to be there to hold things together.' 
Several interviewees noted that some of the functions now increasingly expected of destination groups -in particular research and data analysis- had in fact previously been conducted by RDAs, and that RDAs had served an important co-ordinating role, for instance, in bids to the European Union and in facilitating public-private partnerships. Others noted that RDAs had mediated investments in infrastructure, systems and facilities within the regions, and that their long-term survival was threatened by their disbanding. In one example, an interviewee was 'unsure who will pay for the destination management system ..... [that costs] over f1million a year to run .... for the whole of the North East but it is not clear if any of this will survive.' Therefore the challenge before the closure of the RDAs in 2012 was to ensure as much of the legacy was preserved as possible.

Looking forward, $83 \%$ of the destination groups knew they were located in the same territory as one or more of the LEPs. Specific knowledge of LEPs was variable, though. $6 \%$ of respondents were unaware of whether they were located within a LEP boundary and just 20 LEPs were specifically cited (i.e. $57 \%$ of the total) as potential partners for the destination groups. $59 \%$ claimed that they were currently engaging with their local LEP to further tourism development but the proposed new architecture had not yet borne fruit. Lag times were one reason in so far as the LEP was 'very much in its infancy.... It should be clearer within 6-7 months what the LEP is prioritising and budget etc.' In terms of action, there were no successful tourism bids in the first round of the Regional Growth Fund (Tighe and Bounds 2011) and one respondent reported a specific instance of how a tourism bid for the second round had not been put forward by the LEP:

'The problem with the tourism sector is that it is mainly micro businesses with a few big players so it is very difficult to measure and its not easy for "bean counters". Tourism could not give the specific numbers the bid needed, numbers employed etc. so the tourism bid was not made.'

Others noted that the newness of LEPs had prompted the private sector (in general) to treat them warily in their area and this created a dilemma for the destination groups. Until it was far more apparent what the benefits of engaging with LEPs would be, destination groups were dubious as to whether it was wise to invest what limited (staff) resources they had into nurturing relationships with LEPs. Many LEPs did not have budgets in place and there was uncertainty as to whether they would be able to procure investment per se and, if so, at what level. Emblematic of this view, it was noted that on LEPs it '... is still far too early to judge what will happen. We don't want to put in a lot of time and effort to this and then end up with nothing.' Allied to this it was noted that, with a year to go until the ultimate demise of the RDAs, it was unclear precisely how long it would take for the LEPs to become fully conversant with, and introduce systems that would recognise, the specificities of the tourism sector. Moreover, it might take several years (i.e. around half a parliamentary term) until the situation became much clearer. Not surprisingly then, for $86 \%$ of destination groups the current landscape of policy support for tourism was unclear in their area. One respondent summed up the problem:

'the difficulty is it went from something to nothing overnight. Even if regionalism had its problems, at least there was a connection and linkages in place whether the RDA or tourist board up to VE or DCMS. There are not the linkage functions anymore.' 


\section{Discussion: from order to complexity (but not disorder)}

What emerges from investigating these reforms as they have been unfolding is a contested and ambiguous situation. Advocates of new localism would note that the majority of LEPs acknowledged tourism as an issue within their domains and nearly $60 \%$ of the existing destination groups reported that they are engaging with the associated LEPs. Moreover, as Figure 5 indicates, many (but not all) of the destination groups are, in principle, able to provide the types of function envisaged by government policy and on which regional bodies led in the past.

Conversely, critics would point to the turbulence resulting from the recent reforms. Only $20 \%$ of LEPs recognised tourism as a key priority, $34 \%$ recognised tourism as an economic driver, and $31 \%$ acknowledged their leadership function on behalf of the sector. Moreover, there has been increased pressure on reduced public sector funding to achieve more. $78 \%$ of LEPs had not set a budget but would be expected to leverage external funding to cover their operating costs and strategic interventions, while $74 \%$ of destination groups were publicly-led and $67 \%$ had seen public funding cut. For $60 \%$ of LEPs and $86 \%$ of destination groups, the nature of public sector support for tourism was unclear. In the case of destination groups (i.e. DMOs), while nearly $70 \%$ believed that they can contribute in some way to the government's aspiration of enhanced destination management, under half were in fact able to.

Viewed through the Cynefin Framework, since May 2010 there has been a fundamental shift in the approach to, and the nature of, public sector support for tourism in England. Prior to 2010, governance and administration were based on the orthodox ontology of order. Planning for outcomes was the norm and the consequences of investments and policy interventions were at least knowable, sometimes clearly known. Through long-established infrastructures developed and supported by the RTBs and later RDAs, policy and planning were for the most part evidence-based; considerable research on behalf of the sector was conducted to understand the changing nature and importance of visitors, attractions and destination products; and established systems and technologies were in place to enable the appraisal of investment decisions of differing scope (Coles 2008, BERR 2009, BIS 2009). Almost all RTBs conducted research on branding, segments among their visitors and non-visitor surveys (see for example ONE undated, SWTA 2011). Good practices were circulated among communities of practice and best practices were extolled. Scenario planning was used in regional tourism administration utilizing long institutional memories to predict longterm tourism futures (SWT 2010b). In the language of Cynefin, there was considerable evidence of both Visible Order as well as elements of Hidden Order (Table 2, Figure 4) and, as we noted above, the application of the Cynefin Framework is not about the allocation of the data to a single, 'best fit' category. Rather, its strength is the relativities it reveals in relationships.

The removal of the regional layer has, no doubt, within a relatively short space of time engineered conditions of far greater uncertainty and seriously eroded the well-established order. Rather than disorder, 'un-order' has characterized the new system of governance and administration (Table 2): a new but quite different form of order has been emerging in response to the distinctive demands of the Sovereign Debt crisis. This has been exploratory insofar as a regional layer has existed from the late 1960s and central government has taken an active role in the tourism sector over a protracted period. Moreover, this new approach has not been on the basis of a substantial evidence base that irrefutably demonstrates that it will be any the more successful than the previous one. Reform has 
also not been the result of a groundswell of opinion among its interest groups, nor a widespread consultation with the industry (HI 2011; Tourism Alliance 2011).

As a result, for some critics (such as Ibrahim 2011) the situation might be described as chaotic (Figure 4). In their view action has preceded analysis, cause-and-effect have not been (and are not) discernible, and recent reform has been a form of stability-focused intervention or crisis management (Table 2). After all, if central government's assessment of the public finances is accepted, support for tourism (like other forms of public sector spending) had become unsustainable at pre-2010 levels. The new arrangements filled the gaps left by the eradication of RDAs and RTBs. Partnership working and the pooling of resources represented the obvious means by which to respond to budget cuts to local authorities, associated staffing cuts, and commensurate losses in capacity and tacit knowledge to the sector.

A more sympathetic reading is that the situation, as experienced by those on the ground, has been characterised by Complex Unorder (Table 2). DMOs in various guises emerged throughout England in the last decade; they are not entirely unknown; and, while there may not be a substantial evidence base on their effectiveness, efficiency and return on public investment, it clear from the data presented here that, in general terms, they can play the sort of roles central government anticipates. Public-private partnerships have been a feature for some time. With the balance shifted to the private sector to a degree that is untried, new patterns of working will be finalised to match local parameters which will impact on the future vitality and viability of the tourism sector. However, cause and effect will only be knowable in retrospect.

Cynefin is not intended to deliver static categorizations . Rather, the nature of movements across boundaries between domains as well as the directions of travel are almost as important, if not more so, than current designations. Through socially-constructed narratives based on shared group meanings, we can unravel how different constituencies make sense of change with a view to shaping future progress. In this respect, it is important to note that there have been differences in how the main actors have made sense of change (Table 5).

As contended above, the reforms were ideologically motivated (Cameron 2010). In its tourism policy pronouncements, arguably the Coalition Government adopted a position that embedded aspirational narratives that combined elements of both Liberation and Exploration (Tables 5 and 3 ) as the probable trajectories of change. Accompanying the political rhetoric was clearly a strand of Liberation; that is, the situation would change from the known to the knowable, via the complex (Figure 4). Departure from a known and well-understood (but allegedly failing and inefficient) system of public support was enthusiastically advocated as a means to free the sector from the shackles of an unnecessarily bureaucratic regime, arbitrary regional boundaries, and hence to promote growth. As the new approach would represent such a radical departure from past, it would be almost inevitable that there would be great disruption in the short term, as both government policy prescriptions and the experience on the ground have testified. Still, policy was written in such a manner that it anticipated a normalization of arrangements to occur in an as-yet unspecified way as the new arrangements would 'settle down' over the current parliamentary term (Penrose 2011). In this way, the new arrangements can be viewed as knowable and there is a hidden order that is yet to be fully revealed. 
Table 5: Destination groups' positions and possible future trajectories.

\begin{tabular}{|l|l|l|l|}
\hline \multicolumn{2}{|c|}{ Organizational Type } & \multicolumn{1}{c|}{ Main approach/es* } & \multicolumn{1}{c|}{ To } \\
\hline Government & $\begin{array}{l}\text { Liberation } \\
\text { Exploration }\end{array}$ & $\begin{array}{l}\text { Known } \\
\text { Knowable }\end{array}$ & $\begin{array}{l}\text { Knowable } \\
\text { Complex }\end{array}$ \\
\hline LEPs & Swarming & Chaotic & Knowable \\
\hline DMOs & Entrainment Breaking & Knowable & Complex \\
\hline
\end{tabular}

Source: authors

Embedded within this macro perspective of Liberation are elements of Exploration as a form of qualification. Government was not entirely prescriptive in what local arrangements should look like between LEPs and DMOs; nor indeed what precisely DMOs were going to be expected to deliver in service of other policy goals. In this respect the emerging position differs from the previous, 'knowable' situation in so far as the likely contributions from RDAs and RTBs to policy aspirations were more predictable. Instead, a more complex situation was anticipated in which government did not expect all DMOs to contribute to every facet of policy, either equally or at all. Rather, there would be differential contributions to delivery which has, to some extent, already been evident in the work areas that destination groups have identified as priorities (Figure 5). In this trajectory, trust between central government and local actors is not only essential but it is also desirable, and it has featured prominently among the narratives. Local actors have to be trusted to devise and operate their own working arrangements to reflect local tourism contexts. Funding settlements and applications from LEPs (on behalf of local authorities and DMOs) have to be appropriate to local needs. For government, this was ideologically and financially appropriate because it enables 'big government' and public spending to be reduced. What is more, there would appear to have been a failsafe. Central government has ensured that it is likely to retain control because it funds local authorities (which are accountable to it) as major actors in LEPs and DMOs.

Not surprisingly, practitioners in LEPs and DMOs made sense of the reforms and the future direction of travel differently. Rather than liberation or exploring the possibilities of a new approach, some of the more negative responses from DMOs postulated the collapse of an ordered system (Table 3). As we have suggested above, this is a somewhat extreme position and not always justified by the data. On balance though, their experience and perception of change has been more reminiscent of Entrainment Breaking (Table 3). The system before May 2010 had both knowable and known elements but, as the reforms were announced and unfolded, unorder was perceived to have entered the system. The interview data suggest very strongly that the system was believed to be chaotically unordered during the period in $\mathbf{2 0 1 0}$ when the terms of reference for LEPs and later applications to establish LEPs were being decided. Initially then, they had no clear idea of with whom they would be working on tourism policy, planning and development. In the absence of more detailed guidance, DMOs were having to manage in a largely ad hoc manner based on new resource arrangements and staffing structures. Furthermore, these were taking time to stabilise and continue to do so as the effects of the 2010 Comprehensive Spending Review work their way through the system until 2013. Since the LEPs emerged some order emerged, although tourism does not feature as strongly as it could in their agenda. Interview responses and the questionnaire results suggest that the trajectory was towards a complex system, although there was some way to go before the new approach to governance and administration is sufficiently well understood to provide a robust platform from 
which to stimulate local tourism growth. The key loci have been identified but there is relatively limited engagement between them.

Finally, the LEPs' engagement with tourism is perhaps best characterised as 'swarming' (Tables 5 and 3). Until 2010, there were no such entities as LEPs in UK economic development and governance. The nearest analogues were the Enterprise Zones and Urban Development Corporations of the Conservative governments of the 1980s. Thus, almost by definition, their emergence was marked by chaos in so far as there was initially a dearth of detail as to what form they should take, what their terms of reference may entail, and how they may relate to key economic sectors like tourism. Not surprisingly, as more substance was supplied by central government and the application procedure progressed, the format and scope of these organisations became clearer and their relationship to tourism graduated -to employ phraseology from project management- from 'unknown unknown' to 'known unknown'; that is, at first tourism actors had no idea whether tourism featured in the LEP agenda and if so, how so. As this research has demonstrated, more has become known about how tourism features in initial LEP rhetoric. However, a clear variability in perception emerged and it was unclear the extent to which such statements (in terms of funding) could and would translate into action.

Moving forward, perhaps most important of all is the juxtaposition between how practitioners and government made sense of the unfolding situation. As we noted above, Cynefin is intended to be a framework to allow different parties to understand their own positions and those of other stakeholders with greater clarity as a means of devising a more efficient collective way forward. Clearly some key differences were notable in how change was understood. For government, the reforms were supposed to be enabling in nature and designed to stimulate further private sector engagement with, and investment in, a sector which it could no longer support at historically high levels of public spending. For DMOs these reforms represented an impediment to current and future development because the public sector will have to achieve more with far less resource. Furthermore, the nature of the tourism sector suggested very strongly that the private sector will not fill the shortfall as government anticipated.

Of course only time will tell whether these reforms prove a success and/or whether there has to be movement in the government's position on public sector support for tourism or the private sector engages more as anticipated. Assuming both sides stick to their stated positions, current uncertainty and complexity allied with even greater funding constraints in the future suggest that some of the government's targets for growth and productivity gains may be somewhat infeasible in the short term (Table 1). What is more, there is a danger that the problem may be compounded. Current arrangements may not be 'fit for purpose' in the medium-term. As Kurtz and Snowden (2003: 469) would put it, 'once a pattern has stabilised, its path appears logical' but the danger with complexity is that 'structured methods that seize upon such retrospectively coherent patterns and codify them into procedures will confront only new and different patterns for which they are ill prepared'. Recasting the argument, governance structures or administrative arrangements designed to address conditions in $\mathbf{2 0 1 0}$ may not be relevant for the realisation of policy ambitions later in the parliamentary term when public spending is expected to be under control, the downturn over, and tourism will grow in the aftermath of London 2012 (Penrose 2011). 


\section{Conclusion}

The landscape of public sector support for tourism in England has been radically altered in the short time since the Coalition Government was elected in May 2010. Ideological motivations to reduce 'big government', to place local communities at the heart of the recovery, and to cut the deficit have resulted in a mosaic of DMOs and LEPs filling the gaps left by the removal of regional bodies at a time when public spending on tourism has been reduced. The implementation of a largely untested system for tourism governance and administration has been met with high levels of uncertainty among practitioners in both the LEPs and DMOs. An ordered and known system has been supplanted by another, more complex form of order but not total disorder. While several hallmarks of chaos have been evident so far, through trajectories of Swarming and Entrainment Breaking the current situation is typically perceived as unwelcome in its inherent complexity. Politicians and policy-makers anticipate a normalization of the system and a progression to more ordered, effective and even efficient system of governance and administration. However, in the view of DMOs in particular, this is unlikely in the short term as the full effects of the recent cuts in public spending are yet to be felt by local authorities and LEPs.

There are two main implications of this study for further research. First, studies of tourism and public policy have, for the most part, been conducted against a backdrop of relative economic stability, growth and prosperity. Moreover, they have largely explored ways in which to widen and strengthen engagement with the public sector. As this paper has demonstrated, they are not always well-positioned to contribute to a deeper understanding of change as the public sector shrinks. Seldom have they had to deal with withdrawal of public sector support nor how such a radical change as the entire removal of a layer of public administration is experienced. In this regard, there is considerable value in employing sense-making frameworks which are utilized elsewhere in management studies. Of course, the Cynefin Framework is just one among several that could be used to interpret recent developments as they are experienced in a range of private, private and voluntary bodies in the tourism sector (Browning and Boudes 2005). However, one of Cynefin's principal strengths is that it challenges the orthodox ontology of order and the normative nature of much research on tourism policy, and it encourages a more iterative and extended engagement between researcher and subject. As a second implication, further empirical research is required on the changing nature of tourism policy and planning during the current Sovereign Debt crisis. This is an important lacuna. The UK has by no means been unique among developed economies in cutting public spending. However, more detailed knowledge is lacking on the extent to which other states have maintained or reduced public sector support for tourism, and the impact of the various approaches. Conditions do not remain constant across entire recessionary episodes. As such, further research would be welcome on how change is experienced at different points within the current economic downturn. Not only would this be helpful in future episodes, but it may also have great resonance if recovery from the current financial crisis is more protracted than current forecasts suggest.

\section{Acknowledgements}

The authors would like to acknowledge the support of the Economic and Social Research Council (ESRC) in the UK in the form of a Placement Award (Hutchison) as part of its Capacity Building Cluster scheme (RES-187-24-002). The research benefitted in its early stages from the advice and facilitation of VisitEngland and DP:UK. The usual caveats apply, not least that the opinions expressed in this paper are those of the research team alone. 


\section{References}

Allmendinger, P. and Tewder-Jones, M. (2000) 'Spatial dimensions and institutional uncertainties of planning and the "new regionalism"', Environment and Planning C, 18: 711-726.

Anastasiadou, C. (2008) 'Tourism interest groups in the EU policy arena: characteristics, relationships and challenges', Current Issues in Tourism, 11(1): 24-62.

Appleyard, N. (2010) RDAs Braced for Budget Cuts. Local Gov. Website. Available from: http://www.localgov.co.uk/index.cfm?method=news.detail\&id=89062 [Last accessed: 5 May 2011].

Beeton, S. (2008) 'Partnerships and social responsibility: leveraging tourism and international film business' in Coles, T.E. and Hall, C.M. (eds.) International Business and Tourism: Global Issues, Contemporary Interactions. London: Routledge, 256-272.

Birmingham and Solihull LEP (2010) The Local Enterprise Partnership: for Birmingham and Solihull with East Staffordshire, Lichfield and Tamworth. Available from: http://www.wmcouncils.gov.uk/media/upload/Economy\%20\&\%20Skills/Birmingham,\%20So lihull,\%22Lichfield,\%20Tamworth\%20\&\%20East\%20Staffs\%20LEP.pdf [Last accessed 28 June 2011].

Blackman T. and Ormston C. (2005) 'Discourses of accountability: policy scrutiny of an English regional development agency', Regional Studies, 39: 375-386.

Bounds, A. (2011) 'LEPs to receive an extra f5m funding', FT.com, May 132011.

Bramwell, B. and Lane, B. (eds.) (2003) Tourism Collaboration and Partnerships: Politics, Practice and Sustainability. Clevedon: Channel View Publications.

Bramwell, B. and Lane, B. (eds.) (2011) Tourism Governance: Critical Perspectives on Governance and Sustainability. London: Routledge.

British Broadcasting Corporation (BBC) (2010a) UK budget deficit revised lower by ONS. Online document (21/05/10). Available from: http://www.bbc.co.uk/news/10136055 [Last accessed: 23/07/10].

British Broadcasting Corporation (BBC) News (2010b). Budget: Regional Development Agencies to be scrapped. Online document. Available from: http://www.bbc.co.uk/news/10391326 [Last accessed: 22 June 2011].

British Broadcasting Corporation (BBC) News (2011). David Cameron: Tourism vital to British Economy. Online document. Available from: http://www.bbc.co.uk/news/uk-politics10950631 [Last accessed: 22 June 2011].

Browning, L. and Boudes, T. (2005) 'The use of narrative to understand and respond to complexity: a comparative analysis of the Cynefin and Weickian models', E:CO, 7(3-4): 35-42.

Business, Enterprise and Regulatory Reform, Department of (BERR, 2009) Impact of RDA Spending. National Report - Volume 1 - Main Report. Online document. Available from: www.bis.gov.uk/files/file50735.pdf [Last accessed: 24/11/11]

Business, Innovation and Skills, Department of (BIS, 2009) RDA Evaluation: Practical Guidance on Implementing the Impact Evaluation Framework. Online document. Available from: www.bis.gov.uk/.../09-1559-rda-evaluation-practical-guidance-main-report.pdf [Last accessed: 24/11/11]

Business, Innovation and Skills, Department of (BIS) (undated a) Local Enterprise Partnerships. Online document. Available from: http://www.bis.gov.uk/policies/economicdevelopment/leps [Last accessed: 28 June 2011].

Business, Innovation and Skills, Department of (BIS) (undated b) LEP Map. Online document. Available from: http://www.bis.gov.uk/assets/biscore/economic-development/docs/l/lepsmap-revised-april-2011-pdf-format.pdf [Last accessed: 12 May 2011]. 
Cabinet Office, The (2010) The Coalition. Our Programme for Government. Online document. Available from: http://www.cabinetoffice.gov.uk/news/coalition-documents [Last accessed: 19/10/11].

Cable, V. \& Pickles, E. (2010). Letter on Local Enterprise Partnerships. Online document. Available from: http://centreforcities.typepad.com/centre_for_cities/2010/06/cablepickles-letter-onlocal-enterprise-partnerships.html [Last accessed: 22 June 2011].

Cameron, D. (2010). PM's Speech on Tourism. Online document. Available from: http://www.number10.gov.uk/news/speeches-and-transcripts/2010/08/pms-speech-ontourism-54479 [Last accessed: 22 June 2011].

Church, A., Ball, R., Bull, C. And Tyler, D. (2000) 'Public policy engagement with British tourism: the national, local and the European Union', Tourism Geographies, 2(3): 312-336.

Coles, T.E. (2003) 'A local reading of a global disaster: some lessons on tourism management from an annus horribilis in Southwest England', Journal of Travel and Tourism Marketing, 15(2/3), pp. 173-197.

Coles, T.E. (2008) 'The implementation of sustainable tourism: a project-based perspective', in Gössling, S., Weaver, D. and Hall, C.M. (eds.) Sustainable Tourism Futures. Perspectives on Innovation, Scale and Restructuring. London, Routledge: 204-221.

Communities and Local Government, Department of (CLG) (2011). Local Government. Online document. Available from:

http://www.communities.gov.uk/newsroom/factsandfigures/local/facts/localgovernment/?i $d=1682861$ [Last accessed: 18 October 2011].

Conservative Party, The (2010) Invitation to Join the Government of Britain. The Conservative Manifesto 2010. Online document. Available from:

http://www.conservatives.com/Policy/Manifesto.aspx. [Last accessed: 19/10/11].

Culture, Media and Support, Department of (DCMS) (2011). Business Plan 2011-2015. Online document. Available from: http://www.number10.gov.uk/wp-content/uploads/DCMSBusiness-Plan1.pdf [Last accessed: 6 June 2011].

Culture, Media and Sport Committee (CMSC), House of Commons (2007) London 2012 Olympic Games and Paralympic Games: Funding and Legacy. Volume 1. London: HMSO (HC 69-I).

Deloitte \& Oxford Economics (2010). The Economic Contribution of the Visitor Economy: UK and the Nations. Online document. Available from:

http://www.visitbritain.org/Images/Economic\%20case\%20for\%20the\%20Visitor\%20Econom y\%20-\%20Phase\%202\%20-\%2026\%20July\%202010\%20-\%20FINAL_tcm139-192073.pdf [Last accessed: 28 June 2011].

D2N2 LEP (2010) Derby, Derbyshire, Nottingham, Nottinghamshire LEP Proposal. Online document. Available from: http://www.nottinghamcity.gov.uk/CHttpHandler.ashx?id=20777\&p=0 [Last accessed: 28 June 2011].

DP: UK (undated) Destination Performance UK, Home. Online document. Available from: http://www.dpuk.org.uk [Last accessed: 22 June 2011].

Dredge, D. and Jenkins, J. (2003a) 'Destination place identity and regional tourism policy', Tourism Geographies, 5(4): 383-407.

Dredge, D. and Jenkins, J. (2003b) 'Federal-state relations and tourism public policy, New South Wales, Australia', Critical Issues in Tourism, 6(5): 415-443.

Dredge, D. and Jenkins, J. (2007) Tourism Planning and Policy. Milton, Queensland: Wiley and Sons.

Dredge, D. and Jenkins, J. (eds.) (2011) Stories of Practice: Tourism Policy and Planning. Basingstoke: Ashgate.

Economist, The (2011) Europe's sovereign-debt crisis - Acropolis now. Online document. Available from: http://www.economist.com/node/16009099 [Last accessed: 26/10/11].

Edgell, D., Del Maestro Allen, M., Smith, G. and Swanson, J.R. (2008) Tourism Policy and Planning. Yesterday, Today and Tomorrow. Oxford: Butterworth-Heinemann. 
England's RDAs (Regional Development Agencies) (2010) Q\&As on the future of RDAs Online document. Available from: http://www.englandsrdas.com/news/qas-on-the-future-of-rdas [Last accessed: 19/10/11].

Fensham, P. (2011) 'Knowledge to deal with challenges to science education from without and within', in Corrigan, D., Dillon, J. and Gunstone, R. (eds.) The Professional Knowledge Base of Science Teaching. Berlin: Springer Verlag.

Franke, M. and John, F. (2011) 'What comes next after recession? Airline industry scenarios and potential end games', Journal of Air Transport Management, 17: 19-26.

French, S., Bedford, T., Pollard, S. and Soane, E. (2011) 'Human reliability analysis: a critique and review for managers', Safety Science, 49: 753-763.

Fuller, C., Bennett, R.J. and Ramsden, M. (2002) 'The economic development role of English RDAs: the need for greater discretionary power', Regional Studies, 36(4): 421-428

Giddens, A. (2010) The rise and fall of New Labour. New Statesman, 15/05/2010. Online document. Available from: http://www.newstatesman.com/uk-politics/2010/05/labourpolicy-policies-blair. [Last accessed: 19/10/11].

Gibbs, D. and Jonas, A. (2001) 'Rescaling and regional governance: the English regional development agencies and the environment', Environment and Planning C, 19: 269-288

Goodwin M., Jones M., Jones R., Pett, K. and Simpson, G. (2002) ‘Devolution and economic governance in the UK: uneven geographies, uneven capacities?' Local Economy, 17(3): 200215.

Goodwin M., Jones M. and Jones R. (2005) 'Devolution, constitutional change and economic development: explaining and understanding the new institutional geographies of the British state', Regional Studies, 39: 421-436.

Government, Her Majesty's (HMG) (2010a). The Coalition: Our Programme for government. Online document. Available from:

http://www.direct.gov.uk/prod_consum_dg/groups/dg_digitalassets/@dg/@en/documents /digitalasset/dg_187876.pdf [Last accessed: 5 May 2011].

Government, Her Majesty's (HMG) (2010b). Local Growth: Realising Every Place's Potential. Online document. Available from: http://www.bis.gov.uk/assets/biscore/economicdevelopment/docs/l/cm7961-local-growth-white-paper.pdf [Last accessed: 22 June 2011].

Greater Manchester LEP (2010) Greater Manchester Local Enterprise Partnership: A Proposal to Government. Online document. Available from: http://neweconomymanchester.com/stories/1335greater_manchester_submits_lep_plans_[Last accessed: 28 June 2011].

Grotan, T., Storseth, F. and Albrechtsen, E. (2011) 'Scientific foundations of addressing risk in complex and dynamic environments', Reliability Engineering and System Safety, 96: 706712.

Hall, C.M. (2005a) 'The role of government in the management of tourism', in Pender, L. And Sharpley, R. (eds.) The Management of Tourism. London: Sage, 217-231.

Hall, C.M. (2005b) Tourism. Rethinking the Social Science of Mobility. Harlow: Pearson.

Hall, C.M. (2008) Tourism Planning. $2^{\text {nd }}$ edition, Harlow: Pearson.

Hall, C.M. (2010) 'Crisis events in tourism: subjects of crisis in tourism', Current Issues in Tourism, 13(5): 401-417.

Hall, C.M. and Valentin, A. (2005) 'Content Analysis', in Ritchie, B.W., Burns, P. and Palmer, C. (eds) Tourism Research Methods. Wallingford: CAB International: 191-201.

Harding, A., Wilks-Heeg, S. And Hutchins, M. (1999) 'Regional development agencies and English regionalisation: the question of accountability', Environment and Planning C, 17(6): 669683.

Henderson, R. and Shutt, R. (2004) 'Responding to a coalfield closure: old issues for a new regional development agency?', Local Economy, 19(1): 25-37. 
Henriksen, P. and Halkier, H. (2009) 'From local promotion towards regional tourism policies: knowledge processes and actor networks in North Jutland, Denmark', European Planning Studies, 17(10): 1445-1462.

Hiscock, J. (2004) 'Developing knowledge management awareness in public relations students', Public Relations Review, 30: 107-115.

Hotel Industry (2010). David Cameron on UK Tourism: Industry reaction. Online document. Available from: http://www.hotel-industry.co.uk/2010/08/uk-tourism/ [Last accessed: 22 June 2011].

Hotel Industry (2011). Tourism Strategy: Industry reaction to new tourism strategy. Online document. Available from: http://www.hotel-industry.co.uk/2011/03/tourism-strategy/ [Last accessed: 22 June 2011].

Hunt, J. (2010). Letter on the Spending Review Settlement to Chair of Visit Britain. Online document. Available from: http://www.culture.gov.uk/images/publications/Rodrigues_Visit_Britain.pdf [Last accessed: 12 May 2011].

Ibrahim, U. (2011). 'Tourism and LEPs', Tourism Society Journal, 146: 5.

Inman, P. (2010) Budget 2010: Plans to turn record debt into surplus cheers City. The Guardian (22/06/10). Online document. Available from: http://www.guardian.co.uk/uk/2010/jun/22/budget-2010-public-sector-cuts [Last accessed: 23/07/10].

Janson, K. (2011). 'Tourism policy: the challenges ahead', Destination UK Magazine, May/June issue: 22.

Jenkins, J. (2000) 'The dynamics of regional tourism organisations in New South Wales, Australia: history, structures and operations', Current Issues in Tourism, 3(3): 175-203.

Jones, M. (2001) 'The rise of the regional state in economic governance: 'partnerships for prosperity' or new scales of state power?', Environment and Planning A, 33(7): 1185-1211.

Jones, M. and Macleod, G. (2004) 'Regional spaces, spaces of regionalism: territory, insurgent politics and the English Question', Transactions of the Institute of British Geographers, 29(4): 433-452.

Jones, P. (2009) 'Impact of the global recession on the hospitality and tourism industry', Tourism and Hospitality Research, 9(4): 363-367.

Kite, M. (2010). 'Coalition announces plans to abolish Regional Development Agencies' The Daily Telegraph 12/06/2010. Online document. Available from: http://www.telegraph.co.uk/news/politics/7823449/Coalition-announces-plans-to-abolishRegional-Development-Agencies.html. [Last accessed: 19/10/11].

Kurtz, C.F. and Snowden, D.J. (2003) 'The new dynamics of strategy: sense-making in a complex and complicated world', IBM Systems Journal, 42(3): 462-483.

Law, J. (2004) After Method. Mess in Social Science Research. London: Routledge.

Lloyd, P. (1999) 'The regional development agencies and social inclusion: widening the agenda', Environment and Planning C, 17(6): 701-713.

Lovering, J. (1999) 'Don't follow us! Welsh lessons for English RDAs', New Economy, 6: 137-40.

Lynch, P. (1999) 'New Labour and the English regional development agencies: devolution as evolution', Regional Studies, 33: 73-78.

The Marches LEP (2010) The Marches Local Enterprise Partnership Proposal. Available from: http://www.wmcouncils.gov.uk/media/upload/Economy\%20\&\%20Skills/The\%20Marches\%2 OLEP.pdf [Last accessed: 28 June 2011].

Mark, A. (2006) 'Notes from a small island: researching organizational behaviour in healthcare from a UK perspective', Journal of Organizational Behaviour, 27: 851-867.

McGehee, N.G., Meng, F. and Tepanon, Y. (2006) 'Understanding legislators and their perceptions of the tourism industry: the case of North Carolina, USA, 1990 and 2003', Tourism Management, 27(4): 684-694. 
Mellows-Facer, A. (2011a). Local Enterprise Partnerships. Online document. Available from: http://www.parliament.uk/briefingpapers/commons/lib/research/briefings/SNEP-05651.pdf [Last accessed: 12 May 2011].

Mellows-Facer, A. (2011b). Regional Growth Fund. Online document. Available from: http://www.parliament.uk/briefingpapers/commons/lib/research/briefings/snep-05874.pdf [Last accessed: 12 May 2011].

Michaels, S. (2009) 'Matching knowledge brokering strategies to environmental policy problems and settings', Environmental Science and Policy, 12: 994-1011.

Mordue, T. (1999) 'Heartbeat Country: conflicting values, coinciding visions', Environment and Planning A, 31(4): 629-646.

Murphy, P. and Murphy, A. (2008) Strategic Management for Tourism Communities. Bridging the Gaps. Clevedon: Channel View.

New Anglia LEP (2010) New Anglia Local Enterprise Partnership for Norfolk and Suffolk. Available from: http://www.newanglia.co.uk/Downloads/Norfolk-Suffolk-LEP.pdf [Last accessed: 28 June 2011].

O'Brien, A. (2010) 'Beyond policy-making: institutional regimes, the state and policy implementation in the Irish case', Current Issues in Tourism, 13(6): 563-577.

One North East (undated) Existing and Emerging Markets. Online document. Available from: http://www.tourismnortheast.co.uk/research-and-statistics/existing-and-emerging-markets [Last accessed: 24/11/11]

Pechlaner, H. and Frehse, J. (2010) 'Financial crisis and tourism' in Conrady, R. And Buck, M. (eds.) Trends and Issues in Global Tourism 2010. Berlin: Spring Verlag, 27-38.

Peck, F. And McGuinness, D. (2003) 'Regional development agencies and cluster strategies: engaging the knowledge-base in the North of England', Local Economy, 18(1): 49-62.

Penrose, J. (2011). Government Tourism Policy. Online document. Available from: http://www.culture.gov.uk/images/publications/Government2_Tourism_Policy_2011.pdf [Last accessed: 20 April 2011].

Pforr, C. (2005) 'Three lenses of analysis for the study of tourism public policy: a case from Northern Australia', Current Issues in Tourism 8: 323-343.

Prokkola, E-K. (2011) 'Regionalization, tourism development and partnership: the European Union's North Calotte Sub-programme of INTERREG III A North', Tourism Geographies, 13(4): 507-530.

Reinhardt, U. (2011) 'Closer, shorter, cheaper: how sustainable is this trend?' in Conrady, R. And Buck, M. (eds.) Trends and Issues in Global Tourism 2011. Berlin: Spring Verlag, 27-36.

Richardson, H. (1978) Regional and Urban Economics. Harmondsworth: Penguin.

Ringland, G. (2010) 'Frameworks for coping with post-normal times: a response to Ziauddin Sardar', Futures, 42: 633-639.

Shaw, G., Thornton, P. and Williams, A.M. (1998) 'The United Kingdom: market trends and policy responses', in: Williams, A.M. and Shaw, G. (1998) Tourism and Economic Development: European Experiences. Chichester: Wiley, $3^{\text {rd }}$ edition: 199-220.

Sheffield City Region LEP (2010) Proposal for a Sheffield City Region Local Enterprise Partnership. Online document. Available from: http://www.sheffieldcityregion.org.uk/local-enterprisepartnership/background [Last accessed: 28 June 2011].

Shepherd, R., Barker, G., French, S., Hart, A., Maule, J. and Cassidy, A. (2006) 'Managing food chain risks: integrating technical and stakeholder perspectives on uncertainty', Journal of Agricultural Economics, 57(2): 313-327.

Skeens, N. (2007) Creating Prosperity in Every Region. Online document. Available from: [Last accessed: 6/10/11]

Smeral, E. (2009) 'The impact of the financial and economic crisis on European tourism', Journal of Travel Research, 48(1): 3-13. 
Smeral, E. (2010) 'Impacts of the world recession and economic crisis on tourism: forecasts and potential risks', Journal of Travel Research, 49(1): 31-38.

Smith, R.A. (2011) 'Global lodging trends have unique regional flairs', Cornell Hospitality Quarterly, 52(3): 226-27.

Snowden, D. (2002) 'Complex acts of knowing: paradox and descriptive self-awareness', Journal of Knowledge Management, 6(2): 100-11.

Snowden, D. (2005) 'Strategy in the context of uncertainty', Handbook of Business Strategy, 6(1): 47-54.

Snowden, D. and Boone, M.E. (2007) 'A leaders framework for decision-making', Harvard Business Review, November 2007.

Solent LEP (2010) Solent Local Enterprise Partnership Outline Proposal. Online document. Available from: http://www.solentlep.org.uk/Solent_LEP_final.pdf [Last accessed: 28 June 2011].

Southwest Tourism (SWT, 2010a) South West Tourism Trends and Forecasts. Unpublished discussion paper prepared for Strategy Refresh Workshops. Exeter: Southwest Tourism.

Southwest Tourism (SWT, 2010b) 2020 Tourism. Tourism in the South West. Understanding what the Future might hold and how we can shape it. Unpublished discussion paper - January 2010. Exeter: Southwest Tourism.

South West Tourism Alliance, The (SWTA, 2011) Research, Facts and Figure. Online document. Available from: http://www.swtourismalliance.org.uk/research-facts-and-figures/nonregular-research-projects/ [Last accessed: 24/11/11]

Sturmberg, J.P. and Martin, C.M. (2008) 'Knowing - in medicine', Journal of Evaluation in Clinical Practice, 14: 767-770.

Taxpayers' Alliance (n.d.) RDA Grants. Research Note 71. Online document. Available from: www.taxpayersalliance.com/rdagrants.pdf. [Last accessed: 19/10/11]

Tighe C. \& Bounds, A. 2011. 'Industry wins out in bid for growth funding'. The Financial Times, 13 April 2011: 4.

Treasury, Her Majesty's (HMT) (2010) Spending Review 2010. Cm 7942. October 2010. Online document. Available from: http://cdn.hm-treasury.gov.uk/sr2010_completereport.pdf [Last accessed: 18/10/11].

Treuren, G. and Lane, D. (2003) 'The tourism planning process in the context of organised interests, industry structure, state capacity, accumulation and sustainability', Current Issues in Tourism, 6(1): 1-22.

Tourism Alliance (2011). Tourism for Growth: With Tourism Alliance Comments on the Government Tourism Policy 2011. Online document. Available from:

http://www.tourismalliance.com/downloads/TA_294_327.pdf [Last accessed: 6 June 2011].

Tyler, D. and Dinan, C. (2001a) 'Trade and associated groups in the English tourism policy arena' International Journal of Tourism Research, 3(6): 459-476

Tyler, D. and Dinan, C. (2001b) 'The role of interested groups in England's emerging tourism policy network', Current Issues in Tourism, 4(2-4): 210-252

VisitBritain (VB) (2010). VisitBritain and VisitEngland Annual Report and Accounts for year ended 31st March 2010. Online document. Available from: http://www.visitbritain.org/Images/Annual\%20Accounts\%2009\%20-\%2010\%20final_tcm2914130.pdf [Last accessed: 5 May 2011].

VisitEngland et al. (2010). England: A Strategic Framework for Tourism 2010-2020. Online document. Available from:

http://www.visitengland.org/Images/7049_Strategic_Framework_LR_singles2_tcm3017921.pdf [Last accessed: 12 May 2011].

VisitEngland (undated). Corporate Website. Online document. Available from: http://www.visitengland.org/ [Last accessed: 28 June 2011]. 
Waters, R. and Lawton-Smith, H. (2002) 'Regional development agencies and local economic development: scale and competitiveness in high-technology Oxfordshire and Cambridgeshire', European Planning Studies, 5(1): 633-649.

Webb, D. and Collis, C. (2000) 'Regional development agencies and the 'New Regionalism' in England', Regional Studies, 34(9): 857-864.

Woodworth, R. (2009) 'The recession is over (maybe!). Now what?', Cornell Hospitality Quarterly, $50(4), 407-12$.

York and North Yorkshire LEP (2010) A York and North Yorkshire Local Enterprise Partnership. Online document. Available from:

http://www.ynypu.org.uk/documents/YNY\%20LEP\%20response\%20to\%20BIS.pdf [Last accessed: 28 June 2011].

Zach, F. (2012) 'Partners and innovation in American destination marketing organizations', Journal of Travel Research, 51(4): 412-425.

Zahra, A.L. (2010) 'A historical analysis of tourism policy implementation by local government', Journal of Tourism History, 2(2): 83-98. 